\title{
PRECONCEPTUAL ABC DESIGN DEFINITION AND SYSTEM CONFIGURATION LAYOUT APPENDIX A
}

March 1995

Prepared by

Barthold \& Associates, Inc.

132 Seven Oaks Drive

Knoxville, TN 37922

for

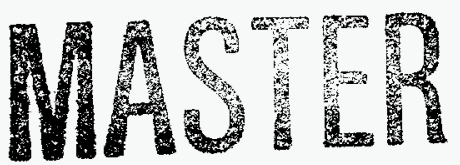

Los Alamos National Laboratory under Subcontract 2254V0015-3Y as Amended 


\section{DISCLAIMER}

Portions of this document may be illegible in electronic image products. Images are produced from the best available original document. 


\section{PRECONCEPTUAL ABC DESIGN DEFINITION AND SYSTEM CONFIGURATION LAYOUT}

\section{APPENDIX A}

March 1995

LIST OF CONTENT

A1: OPERATING CONDITIONS FOR THE STEAM-CYCLE ABC SYSTEM

A2: FLOW RATES AND COMPONENT DIMENSIONS

A3: DRAWINGS FOR THE ABC LAYOUT

A4: IMPACT OF CORE DESIGN PARAMETERS ON CONTAINMENT SIZE

Prepared by

Barthold \& Associates, Inc.

132 Seven Oaks Drive

Knoxville, TN 37922

for

Los Alamos National Laboratory under Subcontract 2254V0015-3Y as Amended 


\section{A1: OPERATING CONDITIONS FOR THE STEAM-CYCLE ABC SYSTEM}

\section{INTRODUCTION}

While the MSBR is the point of reference and departure for the ABC system design, it is important to recognize that the design approach for the $A B C$ system differs significantly from that for the MSBR.

\section{Breeding vs Destruction of Fissile Material}

A careful review of the MSBR design shows that this system was a finely tuned breeder design. To achieve a high breeding gain, the carrier salt could only contain constituents with a very low neutron absorption cross section; furthermore, the carrier salt constituents had to promote neutron moderation. Beryllium was one constituent, and lithium another. However, lithium had to be enriched in ${ }^{7} \mathrm{Li}$ to $99.99 \%$ to be acceptable. Sodium was excluded because of its "high" neutron absorption cross section (the $2200 \mathrm{~m} / \mathrm{s}$ value for sodium is 50 times higher than for beryllium). A gas sparging system to effectively remove $\mathrm{Xe}$ and $\mathrm{Kr}$ from the fuel salt had a very high priority to keep low any breeding penalty. Fission products had to be removed continuously and ${ }^{233} \mathrm{~Pa}$ had to be isolated so as not to lose it due to neutron absorptions in the reactor.

All these issues are of low priority for an ABC system whose mission it is to destroy as effectively as possible the fissile material inserted into the core without producing any new fissile material.

\section{Optimistic vs Realistic Expectations}

During the 1950's and 1960's it was expected that nuclear reactors would dominate the electricity-generating capacity that had to be added to the grid. Projections for the installed nuclear capacity by the year 2000 exceeded $2000 \mathrm{GWe}$. To install such a capacity and ensure fuel supplies for the life of the plants, and to meet a rapidly increasing demand for nuclear power, the ability to breed fuel in a reactor had a very high priority.

The MSBR of the late 1960's and early 1970's was in competition with the LMFBR for breeding and cost performance. Breeding gains for oxide- and metal fueled LMFBRs were expected to be in the range of $0.4-0.55$. Oxide- and metal-fuel LMFBRs were expected to have doubling times of 15 years and less than 10 years, 


\section{PRECONCEPTUAL ABC DESIGN DEFINITION AND SYSTEM CONFIGURATION LAYOUT}

respectively. However, during the 1980's those projected doubling times had risen to $25-30$ years, and 20 years, respectively.

Equally optimistic were the operating conditions for the breeders designed during the late 1960's and early 1970's. Mixed mean outlet temperatures were expected to be in the $1100-1150^{\circ} \mathrm{F}$ range, but dropped to the $875-930^{\circ} \mathrm{F}$ range during the $1980^{\prime} \mathrm{s}$ (the CRBRP had a mixed mean outlet temperature of $975^{\circ} \mathrm{F}$ ).

Thermal efficiencies of $40-45 \%$ were expected during the 1960 's, but the ALMR thermal efficiency was projected to be in the $35-36 \%$ range. Fuel cycle cost was expected to be less than 0.5 mills $/ \mathrm{kWh}$, and capital cost was expected to be in the $\$ 100-120 / \mathrm{kWe}$ range (some PWR turn-key plants were sold at that time at a fixed capital cost of $\$ 85 / \mathrm{kWe}$ installed). We know today that fuel cycle cost are a factor 10 higher, and capital cost are a factor 20 and more higher.

It is, therefore, not surprising that the MSBR with a somewhat marginal breeding gain of only 0.06 and a projected doubling time of over 20 years, to be a successful competitor, had to have low capital cost. This was achieved by keeping fissile inventory cost very low through frequent reprocessing and reducing the out-of-pile inventory, and aiming for a very high thermal efficiency. Duplicating the Bull Run Steam Plant conditions promised a very high thermal efficiency of $44.5 \%$, however, at the expense of 3800 psi pressure'.

\section{Safety Then and Now}

During the 1960's and early 1970's, being able to shut down the reactor in case of an accident was the major safety concern. Safety reports from that time explained, for example, that fuel assembly melting could occur, albeit at a low probability. The reactor would then be shut down, the damaged assembly would be removed and after a short time, upon completion of repair and decontamination work, the reactor would be restarted.

Shutdown reliability is still a major design issue for today's reactors and assurance has to be provided that failure to shut down a reactor has to be an event that is outside the design basis. The major safety concerns today, however, are with reliable decay heat removal in case of an accident and, after the reactor is shut down, the availability of service water as the ultimate heat sink (or a cooling tower), the loss of coolant, and

(1) The MSBR designers were aware that using the Bull Run Steam Plant conditions would introduce design complications and that it might be worthwhile to be less aggressive in terms of steam pressure in favor of design simplification. 
overpower transients resulting from accidents. The early reactor designs showed little in terms of passive and inherent safety features which, today, are mandated for advanced reactors by the NRC. Economics is viewed in the context of safety and reactor availability.

Therefore, for the $A B C$ system design, safety came first, and $A B C$ systems economics has to be achieved within the safety constraints.

\section{DISCLAIMER}

This report was prepared as an account of work sponsored by an agency of the United States Government. Neither the United States Government nor any agency thereof, nor any of their employees, makes any warranty, express or implied, or assumes any legal liability or responsibility for the accuracy, completeness, or usefulness of any information, apparatus, product, or process disclosed, or represents that its use would not infringe privately owned rights. Reference herein to any specific commercial product, process, or service by trade name, trademark, manufacturer, or otherwise does not necessarily constitute or imply its endorsement, recommendation, or favoring by the United States Government or any agency thereof. The views and opinions of authors expressed herein do not necessarily state or reflect those of the United States Government or any agency thereof. 


\section{A1.0 Operating Conditions for the ABC Steam Cycle}

\subsection{ABC primary system operating conditions}

The operating conditions for the $A B C$ system are constrained by the carrier salt selections for the fuel and coolant.

\subsection{1 fuel salt compositions}

For molten salt reactors two chemical fuel forms have been considered, fluorides and chlorides. Fluoride salts have the ability to dissolve large amounts of thorium and uranium fluorides as well as fission product fluorides, show low viscosities and a low vapor pressure at high temperatures. Uranium can easily be separated from the salt in a fluoride volatility process that stems from the high volatility of $U_{6} F_{6}$ (boiling point of less than $100^{\circ} \mathrm{C}$ ) and the low volatility of $\mathrm{UF}_{4}$ (boiling temperature over $1400^{\circ} \mathrm{C}$ ).

Chlorides are less well known than fluorides. Because chlorine is less reactive than fluorine, it is expected that not all fission products would be available in the melt in chloride form. Furthermore, as shown in Table 1, chlorides would have to use enriched chlorine because the neutron absorption cross section for natural chlorine is very high.

Therefore, only the fluoride form of salts has been pursued as a suitable form for reactor applications.

The following constituents for the fuel salt have to be considered:

$$
\begin{aligned}
& \mathrm{LiF} \\
& \mathrm{BeF}_{2} \\
& \mathrm{ZrF}_{4} \\
& \mathrm{NaF} \\
& \mathrm{PuF}_{3}
\end{aligned}
$$

Because the $\mathrm{PuF}_{3}$ concentration will be initially less than 0.05 mole \%, it is assumed that, at least initially, the material properties of the fuel salt are determined by the carrier salt. At one time bismuth fluoride had also been considered. However, because of its reduction by structural materials, it was removed from the list of contenders. 
The preferred configuration for molten salt fuel is a thermal neutron spectrum. This will result in a much lower fissile inventory than in a fast configuration. Thermal spectrum configurations can be achieved by either using an internal graphite moderator, or by surrounding an unmoderated core of small dimensions with a thick graphite reflector.

Table 1: Elements/lsotopes Suitable for High-Temperature Fuels

\begin{tabular}{|l|l|}
\hline MATERIAL & \multicolumn{1}{|c|}{$\sigma_{\text {a }}$} \\
& (barns at $200 \mathrm{~m} / \mathrm{sec}$ \\
\hline \hline Nitrogen-15 & 0.000024 \\
Oxygen & 0.0002 \\
Deuterium & 0.00057 \\
Carbon & 0.0033 \\
Fluorine & $\mathbf{0 . 0 0 9}$ \\
Beryllium & $\mathbf{0 . 0 1 0}$ \\
Bismuth & 0.032 \\
Lithium-7 & $\mathbf{0 . 0 3 3}$ \\
Boron-11 & 0.05 \\
Magnesium & 0.063 \\
Silicon & 0.13 \\
Lead & 0.17 \\
Zirconium & 0.18 \\
Phosphorus & 0.21 \\
Aluminum & 0.23 \\
Hydrogen & 0.33 \\
Calcium & 0.43 \\
Sulfur & 0.49 \\
Sodium & 0.53 \\
Chlorine-37 & 0.56 \\
Tin & 0.6 \\
Cerium & 0.7 \\
Rubidium & 0.7 \\
Chlorine (nat.) & 33.8 \\
Lithium (nat.) & 71 \\
\hline
\end{tabular}

A fast spectrum is difficult to achieve with a molten salt based on fluorides. The German MOSEL project was based on uranium, sodium and beryllium fluorides and achieved only an epithermal spectrum. The MOSEL core was surrounded by a blanket fluid consisting of the same carrier salt but with thorium fluoride as the fertile material. 
For plutonium destruction a fast spectrum might not be optimal because of the solubility limits for $\mathrm{PuF}_{3}$. As fission products build up the plutonium inventory has to increase to maintain the same eigenvalue. The fissile inventory in a fast molten salt reactor would start out very high but then increase less steeply as in a thermal system because of the lower reactivity worth of fission products in such a spectrum. However, it is expected that the solubility limit for $\mathrm{PuF}_{3}$ (and the rare earth trifluorides) is reached earlier than in a thermal system.

The following mixtures of fluorides are candidates for fuel carrier salt:

$$
\begin{aligned}
& \text { LiF-BeF } \\
& \text { LiF-NaF-BeF }_{2} \\
& \text { NaF-BeF }_{2}
\end{aligned}
$$

Additions of $\mathrm{ZrF}_{4}$ have been considered to avoid fuel precipitation in the presence of oxidants.

Table 2 summarizes the material properties of these salts and two additional salts:

$$
\begin{aligned}
& \text { LiF-BeF } \\
& \text { LiF-NaF-BeF } \\
& \text { NaF-BeF }_{2} \\
& \text { LiF-BeF }_{2}-\mathrm{ZrF}_{4}-\mathrm{UF}_{4} \\
& \text { LiF-BeF }_{2}-\mathrm{ThF}_{4}-\mathrm{UF}_{4}
\end{aligned}
$$

The second to last salt is the MSRE fuel salt that was shown for comparison purposes and to illustrate the effect of $\mathrm{ZrF}_{4}$ addition. The last salt is the MSBR salt shown for comparison only.

\section{Option 1: $\quad$ LiF-BeF $_{2}$}

This was the fuel carrier salt and coolant salt for the MSRE. The MSRE operation with partially enriched uranium produced about $500 \mathrm{~g}$ of plutonium and analyses of samples showed that all had stayed with the salt. This salt is well characterized. It was also the carrier salt for the MSBR fuel. This salt contains lithium that needs to be enriched in Li-7 which is costly. Both $\mathrm{Li}-6$ and $\mathrm{Li}-7$ are the main sources for tritium production.

\section{Option 2: $\quad$ LiF-NaF-BeF $_{2}$}

This salt was not considered for the MSBR because it contains sodium which is a strong absorber. However, its liquidus temperature is $130^{\circ} \mathrm{C}$ lower than for the option 
1 carrier salt. This salt contains lithium that needs to be enriched which is costly. Lithium is the main source for tritium production.

\section{Option 3: $\quad$ NaF-BeF $_{2}$}

This salt was not considered for the MSBR because it contains sodium which is a strong neutron absorber. Its liquidus temperature is very close to that of the option 2 carrier salt. Its viscosity is higher but still lower than that of water at $600^{\circ} \mathrm{F}$ which is 86 centipoise. There are no significant differences in the other physical properties.

\section{Option 4: $\quad$ Either of the previous options with a $\mathrm{ZrF}_{4}$ addition}

Table 2 shows that the addition of a small amount of $\mathrm{ZrF}_{4}$ does not change properties significantly. The change in viscosity might very well reflect the reduction in $\mathrm{BeF}_{2}$ and to a lesser extent the addition of $\mathrm{ZFF}_{4}$.

\subsection{2 coolant salt compositions}

Commonly used in other reactors are either water, sodium or helium coolants. However, they are not suited for molten salt reactor applications.

Water leakage into the fuel would lead to the precipitation of fuel and the production of high-pressure steam, hydrogen and oxygen.

Sodium reacts with the fuel in that it would reduce all cations except lithium. Beryllium metal could alloy with structural metals. Pu could precipitate in the primary system and could later lead to an unacceptably high increase in reactivity. Sodium also reacts vigorously with water and steam and produces hydrogen, sodium hydroxide, and sodium oxide.

The use of helium would require a high operating pressure that would negate one of the advantages of the molten salt reactor, namely its low operating pressure characteristic. In case helium would leak into the fuel salt, unacceptably high power surges could result due to the positive reactivity coefficient for voids or bubbles.

Therefore, different types of coolants have to be investigated.

The following candidate compositions for coolant salt are shown in Table 3 and briefly discussed below: 


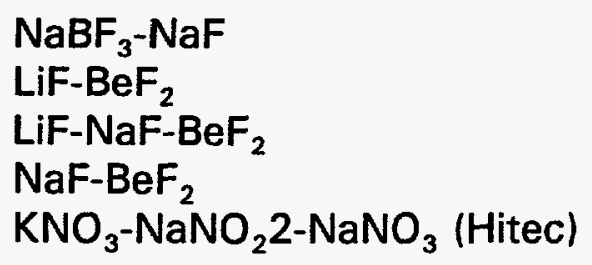

\section{Option 1: $\quad \mathrm{NaBF}_{3}-\mathrm{NaF}$}

The main reasons for selecting sodium fluoroborate instead of $\mathrm{LFF}_{-} \mathrm{BeF}_{2}$ as the MSBR coolant were:

1. avoiding the high cost for using enriched $\mathrm{Li}-7$

2. avoiding the high freezing point of the MSRE coolant

The principal advantages of sodium fluoroborate are the low cost, low viscosity, and its capability to trap tritium. There are claims that tritium would be completely trapped in this coolant, however, the experimental data available for review do not support this claim. In its pure form, it is not corrosive to all major or minor constituents of structural metal alloys.

The chief disadvantage of this coolant arises from its mixing with fuel salt during an accident. This leads to the generation of $\mathrm{BF}_{3}$ gas and probably a redistribution of fissile material between immiscible phases. Other disadvantages of this coolant salt are its thermal decomposition that produces $\mathrm{BF}_{3}$, and its reaction with steam. In case of steam inleakage, metal corrosion can be greatly increased. In case the coolant leaks into the steam system, the $\mathrm{pH}$ of water will be changed due to the formation of HF with fluoride-containing salts and the water will also contain ppm concentrations of fluorides. There is the potential for stress-corrosion cracking.

The decomposition of the coolant leaves most of the $\mathrm{BF}_{3}$ in the salt, but some of it can be swept out of the pump bowl by the required sweep gas. If $\mathrm{BF}_{3}$ is not added, the coolant will slowly change its composition and increase in freezing point. The $\mathrm{He}_{\mathrm{e}} \mathrm{BF}_{3}$ mixture cannot be continuously discharged because of the toxicity and chemical reactivity of $\mathrm{BF}_{3}$ and the need to recover helium. If $\mathrm{BF}_{3}$ is released into the off-gas system, it may react with the charcoal beds.

\section{Option 2: $\quad{ }_{\text {LiF-BeF }}$}

This salt is fully compatible with the fuel salt as demonstrated in the MSRE. Lithium is present in form of $\mathrm{Li}-7$ to prevent discarding all fuel salt in case of a leak of the 
coolant into the fuel salt.

In the MSRE, heat was transferred from the coolant at $546^{\circ} \mathrm{C}\left(1015^{\circ} \mathrm{F}\right)$ to a lowefficiency, air-cooled radiator. In the MSBR, the coolant has to transport the heat to portions of a steam system at much lower temperatures than $546^{\circ} \mathrm{C}$. For coolants with LiF contents of $60-67$ mole \%, the freezing points are between 440 and 460 ${ }^{\circ} \mathrm{C}$. To prevent this coolant salt from freezing in the steam-producing equipment would require an abnormally high feedwater temperature, resulting in a decrease in thermal efficiency. It had been estimated that about a $10 \%$ drop in thermal efficiency would occur in a supercritical steam cycle when the feedwater temperature would have to be increased from $700^{\circ} \mathrm{F}\left(371^{\circ} \mathrm{C}\right)$ to $800^{\circ} \mathrm{F}\left(426^{\circ} \mathrm{C}\right)$.

Furthermore, this coolant is ineffective in trapping tritium.

\section{Option 3: $\quad{ }^{7}$ LiF-NaF-BeF 2}

This coolant is compatible with the fuel salt. It has a low freezing point (that is even below that for sodium fluoroborate), and a low vapor pressure. In its pure form, it is not corrosive to all major or minor constituents of structural metal alloys.

Its disadvantages are its high cost due to the enrichment of Li, its increased corrosivity when mixed with steam (similar to that for sodium fluoroborate), and its inefficiency in trapping tritium.

\section{Option 4: $\quad$ NaF-BeF $_{2}$}

Based on material properties, this seems to be a very desirable coolant salt. It has not been pursued for MSBR applications, probably because (1) in case of a leak into the fuel, a complex cleanup would be required, and (2) NaF could not be present in a marginal breeder like the MSBR. Furthermore, its ability to trap tritium has not been investigated.

\section{Option 5: $\quad \underline{\mathrm{KNO}}_{3}-\mathrm{NaNO}_{2} \underline{2-N a N O}_{3}$ (Hitec)}

The main advantages for this coolant are (1) its low melting point, (2) it is inexpensive and (3) it allows the use of carbon steel up to $850^{\circ} \mathrm{F}$, and above this temperature stainless steel. It is also expected to trap tritium.

Its disadvantages are its violent reaction with graphite if a leak occurred in the IHX, its stability in a radiation field at high temperatures and the need for salt processing in case of a leak. 


\subsection{3 primary system options}

Because of its violent reaction with moderator or reflector graphite, Hitec is eliminated from any consideration in the primary system. The other fuel-coolant combinations are briefly characterized in Table 4.

For the characterization of the fuel-coolant combination the following issues have to be addressed:

- do fuel and coolant react when mixed?

- is tritium produced in the fuel?

- if tritium is produced, does the coolant trap the tritium?

- if coolant leaks into fuel, is fuel processing required?

- melting point of coolant

- cost of coolant and fuel carrier salts

- is the coolant salt stable?

- is the fuel salt a strong neutron absorber?

These topics are briefly summarized in Table. 4.

\subsection{4 proposed primary system operating conditions}

Based on the evaluation of the different fuel-coolant salt combinations, at this time, it would be prudent to use:

- $\quad$ LiF-BeF - PuF $_{3}-\left(\mathrm{ZrF}_{4}\right)$ as fuel

- $\mathrm{NaBF}_{3}-\mathrm{NaF}$ as coolant

These two salts have been investigated extensively under the MSBR Program. They are, by and large, well characterized. However, these choices are less than optimal for a Pu destroyer.

It is recommended to investigate also:

- NaF-BeF $2-\mathrm{PuF}_{3}$ as fuel

- NaF-BeF 2 as coolant.

This combination has the following advantages: 
1. for all practical purposes, no tritium is produced

2. the melting point for this fuel is $220^{\circ} \mathrm{F}$ lower than for the $\mathrm{LiF}-\mathrm{BeF}_{2}$-based fuel

3. the melting point of this coolant is slightly lower than that for the sodium fluoroborate coolant

4. fuel and coolant are fully compatible

5 the coolant is thermally stable

6. the cost for the carrier salt is low; no enrichment services are required

Potential disadvantages are:

1. sodium is a much stronger neutron absorber than lithium

2. the neutron spectrum is slightly harder than for the LiF-BeF2 carrier salt which requires a slightly higher Pu inventory, but results in slightly lower negative reactivity worth of the fission products

However, it is conceivable that the advantages of the NaF-BeF ${ }_{2}$-based salts can far outweigh the disadvantages. In regard to inventory requirements, later in life, the fissile inventory requirements are governed by the accumulated fission products in the core. l.e., the hardening of the spectrum due to the substitution of $\mathrm{Li}$ by $\mathrm{Na}$ has little effect. 


\section{PRECONCEPTUAL ABC DESIGN DEFINITION AND SYSTEM CONFIGURATION LAYOUT}

Table 2: Properties of Different Fuel Carrier Salts

\begin{tabular}{|c|c|c|c|c|c|}
\hline $\begin{array}{l}\text { Composition } \\
\text { (mole \%) }\end{array}$ & $\begin{array}{ll}\text { LiF* }^{*} & (65) \\
\text { BeF2 } & (29.1) \\
\text { ZrF4 } & (5) \\
\text { UF4 } & (0.9)\end{array}$ & $\begin{array}{ll}\text { LiF } & (66) \\
\text { BeF2 } & (34)\end{array}$ & $\begin{array}{ll}\text { LiF } & (23) \\
\text { NaF } & (41) \\
\text { BeF2 } & (36)\end{array}$ & $\begin{array}{ll}\mathrm{NaF} & (57) \\
\mathrm{BeF} 2 & (43)\end{array}$ & $\begin{array}{ll}\text { LiF*** } & (71.7) \\
\text { BeF2 } & (16) \\
\text { ThF4 } & (12) \\
\text { UF4 } & (0.3)\end{array}$ \\
\hline Liquidus Temperature, C ( F) & $434(813)$ & $458(856)$ & $328(622)$ & $340(634)$ & $500(932)$ \\
\hline \multicolumn{6}{|l|}{ Physical Properties at $850 \mathrm{~F}(454 \mathrm{C})$} \\
\hline Density (lb/ft3) & 141 & 125.5 & 136 & 139 & 206 \\
\hline Heat Capacity, (Btu-lb-1- F-1) & 0.47 & 0.57 & 0.47 & 0.44 & 0.33 \\
\hline Viscosity (centipoise) & 10 & 40.4 & 40 & 65 & 12 \\
\hline Vapor Pressure at $1125 \mathrm{~F}(607 \mathrm{C})$ in $(\mathrm{mm})$ & negligible & negligible & negligible & negligible & negligible \\
\hline Thermal Conductivity, (watts/ C-cm) & 0.01 & 0.01 & 0.01 & 0.01 & 0.008 \\
\hline
\end{tabular}

* MSRE fuel salt; cited because it shows the effect of the ZrF4 addition on properties

* * MSBR fuel salt composition is shown for comparison only 


\section{PRECONCEPTUAL ABC DESIGN DEFINITION AND SYSTEM CONFIGURATION LAYOUT}

Table 3: Properties of Different Coolant Salts

\begin{tabular}{|c|c|c|c|c|c|}
\hline $\begin{array}{l}\text { Composition } \\
\text { (mole \%) }\end{array}$ & \begin{tabular}{|ll}
$\mathrm{NaBF} 3$ & $(92)$ \\
$\mathrm{NaF}$ & $(8)$
\end{tabular} & $\begin{array}{ll}\text { LiF } & (66) \\
\text { BeF2 } & (34)\end{array}$ & $\begin{array}{ll}\mathrm{LiF} & (23) \\
\text { NaF } & (41) \\
\text { BeF2 } & (36)\end{array}$ & $\begin{array}{ll}\mathrm{NaF} & (57) \\
\mathrm{BeF} 2 & (43)\end{array}$ & $\begin{array}{l}\text { KNO3 (53) } \\
\text { NaNO2 (40) } \\
\text { NaNO3 (7) }\end{array}$ \\
\hline Liquidus Temperature, C ( F) & $385(725)$ & $458(856)$ & $328(622)$ & $340(634)$ & $109(228)$ \\
\hline \multicolumn{6}{|l|}{ Physical Properties at $850 \mathrm{~F}(454 \mathrm{C})$} \\
\hline Density (lb/ft3) & 121 & 125.5 & 136 & 139 & 108 \\
\hline Heat Capacity, (Btu-Ib-1 - F-1) & 0.36 & 0.57 & 0.47 & 0.44 & 0.37 \\
\hline Viscosity (centipoise) & 2 & 40.4 & 40 & 65 & 3.1 \\
\hline Vapor Pressure at $1125 \mathrm{~F}(607 \mathrm{C})$ in $(\mathrm{mm})$ & $200^{*}$ & negligible & negligible & negligible & negligible \\
\hline Thermal Conductivity, (watts/ C-cm) & 0.005 & 0.01 & 0.01 & 0.01 & 0.33 \\
\hline
\end{tabular}

* $\quad$ pressure of $\mathrm{BF}_{3}$ in equilibrium with this melt composition 


\section{PRECONCEPTUAL ABC DESIGN DEFINITION AND SYSTEM CONFIGURATION LAYOUT}

Table 4: Primary System Options Characteristics

\begin{tabular}{|c|c|c|c|}
\hline FUEL & COOLANT & ADVANTAGES & DISADVANTAGES \\
\hline LiF-BeF2-PuF3 & LiF-BeF2 & $\begin{array}{l}\text { extensive MSRE experience } \\
\text { compatibility } \\
\text { no processing required in case of leaks }\end{array}$ & $\begin{array}{l}\text { high cost fuel and coolant } \\
\text { high melting point } \\
\text { tritium production } \\
\text { no tritium trapping }\end{array}$ \\
\hline LiF-BeF2-PuF3 & NaBF3-NaF & $\begin{array}{l}\text { extensive fuel experience } \\
\text { low coolant melting point } \\
\text { tritium trapping in coolant } \\
\text { low cost coolant }\end{array}$ & $\begin{array}{l}\text { high cost fuel and coolant } \\
\text { fuel-coolant reaction } \\
\text { thermal decomposition of coolant } \\
\text { handling of BF3 } \\
\text { tritium production } \\
\text { fuel processing in case of leaks }\end{array}$ \\
\hline LiF-BeF2-PuF3 & NaF-BeF2-LiF & $\begin{array}{l}\text { extensive fuel experience } \\
\text { fuel/coolant compatibility } \\
\text { low coolant melting point } \\
\text { high cost for } 7 \mathrm{Li}\end{array}$ & $\begin{array}{l}\text { high cost fuel and coolant } \\
\text { tritium production } \\
\text { no tritium trapping } \\
\text { fuel processing in case of leaks }\end{array}$ \\
\hline LiF-BeF2-PuF3 & NaF-BeF2 & $\begin{array}{l}\text { extensive fuel experience } \\
\text { fuel/coolant compatibility } \\
\text { low coolant melting point } \\
\text { low coolant cost }\end{array}$ & $\begin{array}{l}\text { high cost fuel and coolant } \\
\text { tritium production } \\
\text { no tritium trapping } \\
\text { fuel processing in case of leaks }\end{array}$ \\
\hline NaF-BeP2-LiF-PuF3 & LiF-BeF2 & $\begin{array}{l}\text { part of LiF is replaced by } \mathrm{NaF} \\
\text { (lower cost, less tritium production) } \\
\text { fuel/coolant compatible } \\
\text { no processing required in case of a leak }\end{array}$ & $\begin{array}{l}\text { high melting point coolant } \\
\text { high cost coolant } \\
\text { tritium production } \\
\text { no tritium trapping }\end{array}$ \\
\hline
\end{tabular}




\section{PRECONCEPTUAL ABC DESIGN DEFINITION AND SYSTEM CONFIGURATION LAYOUT}

\begin{tabular}{|c|c|c|c|}
\hline NaF-BeF2-LiF-PuF3 & NaBF3-NaF & $\begin{array}{l}\text { part of LiF is replaced by } \mathrm{NaF} \\
\text { (lower cost, less tritium production) } \\
\text { low melting point coolant } \\
\text { tritium trapping in coolant } \\
\text { low cost coolant }\end{array}$ & $\begin{array}{l}\text { fuel-coolant reaction } \\
\text { thermal decomposition of coolant } \\
\text { handling of BF3 } \\
\text { tritium production } \\
\text { fuel processing in case of leak }\end{array}$ \\
\hline NaF-BeF2-LiF-PuF3 & NaF-BeF2-LiF & $\begin{array}{l}\text { part of LiF is replaced by } \mathrm{NaF} \\
\text { (lower cost, less tritium production) } \\
\text { low melting point coolant } \\
\text { low cost coolant } \\
\text { fuel/coolant compatible }\end{array}$ & $\begin{array}{l}\text { high cost coolant } \\
\text { tritium production } \\
\text { no tritium trapping }\end{array}$ \\
\hline NaF-BeF2-LiF-PuF3 & NaF-BeF2 & $\begin{array}{l}\text { part of LiF is replaced by } \mathrm{NaF} \\
\text { (lower cost, less tritium production) } \\
\text { low melting point coolant } \\
\text { fuel/coolant compatible }\end{array}$ & $\begin{array}{l}\text { tritium production } \\
\text { no tritium trapping }\end{array}$ \\
\hline NaF-BeF2-PuF3 & LiF-BeF2 & $\begin{array}{l}\text { low melting point fuel } \\
\text { no tritium production } \\
\text { fuel/coolant compatible } \\
\text { low cost fuel }\end{array}$ & $\begin{array}{l}\text { high cost coolant } \\
\text { high melting point coolant } \\
\text { sodium absorptions } \\
\text { fuel processing in case of leaks }\end{array}$ \\
\hline NaF-BeF2-PuF3 & NaBF3-NaF & $\begin{array}{l}\text { low melting point fuel } \\
\text { no tritium production } \\
\text { low cost fuel } \\
\text { low cost coolant }\end{array}$ & $\begin{array}{l}\text { fuel/coolant reaction } \\
\text { thermal decomposition of coolant } \\
\text { handling of BF3 } \\
\text { fuel processing in case of leaks }\end{array}$ \\
\hline NaF-BeF2-PuF3 & NaF-BeF2-LiF & $\begin{array}{l}\text { low melting point fuel } \\
\text { no tritium production } \\
\text { low cost fuel } \\
\text { fuel/coolant compatible }\end{array}$ & $\begin{array}{l}\text { high cost coolant } \\
\text { sodium absorptions }\end{array}$ \\
\hline
\end{tabular}

\section{REVISION 0}


PRECONCEPTUAL ABC DESIGN DEFINITION AND SYSTEM CONFIGURATION LAYOUT

\begin{tabular}{|l|l|l|l||}
\hline NaF-BeF2-PuF3 & NaF-BeF2 & $\begin{array}{l}\text { low melting point fuel } \\
\text { low melting point coolant } \\
\text { no tritium production } \\
\text { low cost fuel } \\
\text { low cost coolant } \\
\text { fuel/coolant compatible }\end{array}$ & sodium absorptions \\
\hline
\end{tabular}




\section{2 evaluation of steam cycle conditions}

At the time different breeder options were considered (i.e., the late 1960's), the LMFBR fuel cycle required a large centrally located reprocessing and refabrication plant that served between 25-50 GWe of installed capacity. This lowered the unit cost for reprocessing and refabrication and was one of the reasons why an EBR-II-type breeder with metallic fuel and an integrated fuel cycle was eliminated. Not unlike the EBR-II-type breeder, the MSBR was proposed as a breeder with its own reprocessing plant. To offset any cost penalty coming from the larger capital investment, the MSBR designers aimed for as high a thermal efficiency as possible to reduce power cost.

\subsubsection{MSBR supercritical steam cycle}

The MSBR copied the steam conditions for the Bull Run Steam Plant, a very large coalfired electricity generating plant just outside of Oak Ridge, $\mathrm{TN}^{2}$. Table 5 shows the steam conditions and steam generator design for the MSBR.

When applied to the MSBR this supercritical steam cycle yielded a net plant thermal efficiency of $44.4 \%$.

However, there were particular requirements for the MSBR. The feedwater supplied to the steam generator had to be at a temperature high enough to avoid coolant-salt freezing. Tentatively, this temperature had been set at $700^{\circ} \mathrm{F}\left(371^{\circ} \mathrm{C}\right)$. It was also assumed that the cold reheat steam must be preheated to $650^{\circ} \mathrm{F}$ before it enters the reheaters. These constraints led to the selection of a system in which the final stage of feedwater heating is by direct mixing with high-pressure steam. This process established the need for pressure-booster pumps in the feedwater line, because after the feedwater is heated to about $700^{\circ} \mathrm{F}$ in the mixing chamber, its pressure must be raised to that of the steam generator inlet pressure of about 3800 psia.

The MSBR required that about $5.1 \times 10^{6} \mathrm{lb} / \mathrm{hr}$ of $551^{\circ} \mathrm{F}$ steam leaving the highpressure turbine exhaust be preheated to about $650^{\circ} \mathrm{F}$ before it enters the reheaters. The arrangement that had been proposed is to reheat the steam by heat exchange with steam at steam generator exit conditions of 3600 psia and $1000^{\circ} \mathrm{F}$. The flowsheet for the supercritical-pressure cycle with feedwater heated by mixing is shown in Fig. 1.

2 This $950 \mathrm{MWe}$ plant supplies steam at 3500 psia and $1000 \mathrm{~F}$ to the turbine throttle, with a reheat to $1000 \mathrm{~F}$. 
It is not clear whether the use of reheat and its improvement in thermal efficiency is sufficiently cost-effective to offset the added complexity and cost for this system. If reheat is not used, external moisture separators are required to prevent excessive moisture in the last stages of the low-pressure turbines. For the MSBR it was tentatively concluded that reheat provides for a somewhat better turbine performance than moisture separation. However, ORNL-4541 makes reference to an LMFBR study of a $2400 \mathrm{psig}, 900^{\circ} \mathrm{F} / 900^{\circ} \mathrm{F}$ steam cycle, comparing moisture separation and steam reheat that concluded that the economic gain for reheat was not sufficient to offset the added complexities and reduction in plant availability.

It is recommended to investigate the reheat cycle in more detail because its elimination would lead to a substantial system simplification through the elimination of the reheaters, the reheat steam preheaters, and the flow proportioners that divide the coolant salt flow between the steam generators and the reheaters, the latter ones being large heat exchangers with coolant salt on the shell side and steam on the tube side.

\subsubsection{MSBR subcritical steam cycle}

During the design of the MSBR it was recognized that the supercritical steam cycle with 3800 psig pressure might be too high for a nuclear power plant, especially for a low-pressure system like the MSBR. A subcritical steam system was investigated for the MSBR with the following results ${ }^{3}$ :

$\begin{array}{ll}\text { Supercritical } & \text { Subcritical } \\ \text { Cycle } & \text { Cycle }\end{array}$

Nominal feed temperature to steam generator, ${ }^{\circ} \mathrm{F}$

Mixing pressure, nominal

Booster pump or steam compressor discharge pressure, psia

Booster pump or steam compressor power requirements, MWe

Steam flow through steam generator, lb/hr

Overall thermal efficiency, \%

3 Table 5.2 taken from ORNL-4541 (June 1971)
700

3500

3800

700

2600

2900

7.4

52

$9.5 \times 10 E+6$

$19 \times 10 E+6$

44.5

41.1 
The subcritical steam cycle is a modified Loeffler cycle shown in Fig. 2. Both cycles use preheating of the cold steam and subsequent reheat. The difference comes from the heating of the feedwater in a subcritical-pressure cycle where the water is being converted to superheated steam in the drum and then compressed and blown into the steam generator that, in essence, is used as a superheater. Instead of the booster pumps used in the supercritical cycle, steam compressors are required to raise the steam pressure.

For both the supercritical and subcritical cycles, other ways to heat the feedwater need to be explored. Among them the use of a high-pressure heat exchanger the heat the feedwater to $700^{\circ} \mathrm{F}$.

The effect of feedwater temperature on performance of the supercritical steam cycle for the MSBR has also been investigated with the following results ${ }^{4}$ :

\begin{tabular}{clll}
$\begin{array}{l}\text { Nominal Feed } \\
\text { Temperature, }{ }^{\circ} \mathrm{F}\end{array}$ & $\begin{array}{l}\text { Booster Pump } \\
\text { Work, MWe }\end{array}$ & $\begin{array}{l}\text { Steam Generator } \\
\text { Flow Rate, lb/hr }\end{array}$ & $\begin{array}{l}\text { Net Plant } \\
\text { Efficiency, \% }\end{array}$ \\
\hline & none required & $7.4 \times 10 \mathrm{E}+6$ & 44.9 \\
700 & 7.4 & $9.5 \times 10 \mathrm{E}+6$ & 44.5 \\
800 & 87 & $28 \times 10 \mathrm{E}+6$ & 41.3 \\
\hline
\end{tabular}

The case with a feedwater temperature of $580^{\circ} \mathrm{F}$ assumes that this is about the highest feed water temperature that can be attained by regenerative feedwater heating. In this case, no special mixer or booster pump would be required, and it was assumed that the reheat steam would not require preheating. For the 700 and $800^{\circ} \mathrm{F}$ feedwater cases, the feedwater is heated by mixing with steam from reheat steam preheaters. The higher the feedwater temperature has to be raised, the higher are the power requirements for the booster pumps and the steam generator flow rates, but the lower are the net plant thermal efficiencies.

4 Table 5.4 taken from ORNL 4541 (June 1971) 


\subsection{3 other steam cycle conditions}

Table 5 summarizes the steam cycle conditions for the CRBRP, the ALMR, CANDU 3 and CANDU Pickering. Among those listed, only CANDU Pickering has been in operation. It is noteworthy that the advanced reactors have by far the largest steam generator capacities.

The size of the MSBR steam generator was prudently selected. It was realized that about 3750 psia fluid pressure on the inside of the tubes imposes very severe environments on the heads and tube sheets. This led to the decision to keep the shell diameter at 18 inches to keep stresses within more tolerable limits. For the otherwise very advanced steam cycle (and because of it), the steam generator size was kept at $121 \mathrm{MW}$, which is the smallest of all the sizes listed.

\subsection{4 proposed steam cycle conditions for the $A B C$}

Instead of a horizontal U-tube steam generator design, a vertical U-tube design is proposed similar to that used in CANDU (see Fig. 3)

The following steam cycle conditions are proposed:

intermediate coolant inlet temperature, ${ }^{\circ} \mathrm{F} \quad 1150$ outlet temperature, ${ }^{\circ} \mathrm{F} \quad 850$

feedwater/steam inlet temperature, ${ }^{\circ} \mathrm{F} \quad 700$ outlet temperature, ${ }^{\circ} \mathrm{F} 1000$ steam pressure, psia $\quad 1000$

These are tentative conditions mostly dictated by safety considerations. Unless it can be justified, no reheat should be employed.

The steam pressure most likely has to be raised, perhaps even significantly llike to 2400 psia) to achieve a high plant efficiency. However, the safety implications should be assessed carefully. The molten salt system is attractive because of the low vapor pressure of the salt even at very high temperatures that allows for a low operating pressure. This leads to a simplified primary and secondary system design. While the selection of 1000 psia as steam pressure is arbitrary, analysis should support increases to ensure the low-pressure characteristics of the molten salt system is maintained. 
PRECONCEPTUAL ABC DESIGN DEFINITION AND SYSTEM CONFIGURATION LAYOUT

TABLE 5: CHARACTERISTICS OF SOME STEAM GENERATOR DESIGNS

\begin{tabular}{|c|c|c|c|c|c|}
\hline FEATURE & MSBR & ALMR-REF & $\begin{array}{l}\text { ALMR- } \\
\text { MODB }\end{array}$ & CANDU 3 & $\begin{array}{l}\text { CANDU } \\
\text { Pickering }\end{array}$ \\
\hline Type & $\begin{array}{c}\text { horizontal } \\
\text { U-tube }\end{array}$ & helical coil & helical coil & $\begin{array}{c}\text { vertical U- } \\
\text { tube }\end{array}$ & $\begin{array}{l}\text { vertical } \\
\text { U-tube }\end{array}$ \\
\hline $\begin{array}{l}\text { capacity, MW } \\
\text { intermediate coolant } \\
\text { inlet temperature, F } \\
\text { outlet temperature, F } \\
\text { feedwater/steam } \\
\text { inlet temperature, F } \\
\text { outlet temperature, F } \\
\text { feedwater pressure, psia } \\
\text { SG outlet pressure, psia } \\
\text { tube bundle length, ft } \\
\text { \# tubes } \\
\text { overall HT surface, ft-2 } \\
\text { steam flow, } 10 \mathrm{E}+6 \mathrm{lb} / \mathrm{hr} \\
\text { efficiency, } \%\end{array}$ & $\begin{array}{r}121 \\
1150 \\
850 \\
700 \\
1000 \\
3752 \\
3600 \\
76.4 \\
393 \\
3929 \\
0.633 \\
44.4\end{array}$ & $\begin{array}{r}477 \\
864 \\
573 \\
\\
380 \\
830 \\
2072 \\
1800 \\
27 \\
495 \\
31,102 \\
1.6 \\
35.1\end{array}$ & $\begin{array}{r}850 \\
890 \\
619 \\
420 \\
850 \\
2520 \\
2200 \\
40 \\
612 \\
64,089 \\
3.0 \\
36.1\end{array}$ & $\begin{array}{r}689.7 \\
587 \\
514 \\
\\
369 \\
500 \\
667 \\
740 \\
\\
\\
\\
2.74 \\
32.65\end{array}$ & $\begin{array}{r}138 \\
560 \\
480 \\
340 \\
485 \\
593 \\
\\
2600 \\
0.53 \\
29.1\end{array}$ \\
\hline
\end{tabular}




\section{A2.0 Flow Rates and Component Dimensions}

At this time, not a single $A B C$ component or system has been designed. However, to better sketch out a plant layout, an attempt was made to determine flow rates and component dimensions, at the least as rough estimates that help to define a basic layout for the ABC system.

The following basic assumptions were made:

$\begin{array}{ll}\text { module size: } & 750 \mathrm{MWt} \\ \text { average core power density } & 100 \mathrm{MW} / \mathrm{m}^{3} \\ \text { \# of coolant loops per module } & 2 \\ \text { \# of IHX per module } & 2 \\ \text { \# of steam generators per module } & 2 \\ \text { fuel salt constituents } & {\mathrm{LiF}-\mathrm{BeF}_{2}-\mathrm{PuF}_{3}}_{\text {coolant salt }} \mathrm{NaBF}_{3}-\mathrm{NaF} \\ \text { fuel inlet temperature } & 1050^{\circ} \mathrm{F} \\ \text { fuel outlet temperature } & 1300^{\circ} \mathrm{F} \\ \text { moderator fraction in core } & 0 \% \\ \text { core length/diameter ratio } & 1.0 \\ \text { fuel region diameter } & 2.121 \mathrm{~m} \\ \text { fuel flow area in core } & 3.533 \mathrm{~m}^{2} \\ \text { axial/radial reflector thickness: } & 125 \mathrm{~cm} \\ \text { core barrel thickness: } & 2 \mathrm{~cm} \\ \text { gap between core barrel/vessel } & 4 \mathrm{~cm} \\ \text { vessel wall thickness } & 3 \mathrm{~cm} \\ \text { vessel diameter } & 4.80 \mathrm{~m} \\ \text { inner diameter of inner outlet pipe } & 0.381 \mathrm{~m}(15 \text { inches }) \\ \text { wall thickness of inner pipe } & 2.54 \mathrm{~cm}(1 \text { inch) } \\ \text { inner diameter of outer pipe } & 0.557 \mathrm{~m}(21.93 \text { inches }) \\ \text { wall thickness outer pipe } & 2.54 \mathrm{~cm}(1 \text { inch) } \\ \text { outer diameter of outlet/inlet pipes } & 0.582 \mathrm{~m}(22.93 \text { inches }) \\ \text { flow area in inner/outer pipe } & 0.114 \mathrm{~m}\end{array}$

Use was made of double-walled piping for the fuel leaving and returning to the core. The physical properties for the fuel $\left.\right|^{5}$ were those for $\mathrm{BeF}_{2}$ - $\mathrm{LiF}$ because it is assumed that at the least initially the Pu content is close to 0.05 mole $\%$ which is too small to affect physical properties.

5 taken from "Physical Properties of Molten-Salt Reactor Fuel, Coolant, and Flush Salts", by S. Cantor, ORNL-TM-2316 (August 1968), 


\section{1 primary system}

Fuel flow rates were calculated according to:

$P($ power) $=F R$ (flow rate) $\times \mathrm{cp}$ (specific heat) $\times d T$ (temperature rise)

$7.5 \times 10 E+8=F R \times 2385 \mathrm{~J} / \mathrm{kg}-\mathrm{C} \times 138.9 \mathrm{C}$

or

Flow Rate $=2264 \mathrm{~kg} / \mathrm{s}$

The average core flow velocity is calculated from the correlation:

$F R=$ fuel density $(\mathrm{kg} / \mathrm{m} 3) \times$ fuel flow area $(\mathrm{m} 2) \times$ fuel velocity $(\mathrm{m} / \mathrm{s})$

$2264 \mathrm{~kg} / \mathrm{s}=1947 \mathrm{~kg} / \mathrm{m} 3 \times 3.533 \mathrm{~m} 2 \times$ fuel velocity

or

$$
\text { fuel velocity }=0.329 \mathrm{~m} / \mathrm{s}
$$

The volumetric flow rate is calculated from the correlation:

$$
F R=\text { VFR (volumetric flow rate, } \mathrm{m} 3 / \mathrm{s}) \times \text { density }(\mathrm{kg} / \mathrm{m} 3)
$$

or

$$
\text { volumetric flow rate }=1.163 \mathrm{~m}^{3} / \mathrm{s}
$$

The fuel travel time through the core region is $6.4 \mathrm{~s}$.

The outlet flow is conducted through two double-walled pipes, each with a flow of $1132 \mathrm{~kg} / \mathrm{s}$. Using the above-cited correlations, the average fuel velocity in either the outer or inner pipe is $5.18 \mathrm{~m} / \mathrm{s}(17 \mathrm{ft} / \mathrm{s})$.

As shown in section 3, the two pipes separate shortly after leaving the vessel. Heat transfer from the hot to cold fluid should be minimal. 


\section{2 secondary system}

Table 6 compares the MSBR IHX with that for the CRBRP. It is noteworthy that the smaller-capacity IHX for the CRBRP has less than half the tubes of comparable length but is housed in a vessel over twice the height and over $50 \%$ larger diameter than the MSBR IHX. The CRBRP IHX already passed licensing review whereas the MSBR IHX has never been reviewed by the NRC.

The IHX for the ABC system is a scaled-down version of the MSBR IHX design. However, it is assumed that inlet and outlet plena are reached from the sides to eliminate the need for the space on top of the IHX to accommodate the inverted Ushaped outlet/inlet secondary flow arrangement.

For scaling purposes it was assumed that the same MW per meter of tube length applies, and that the tube length is $3.5 \mathrm{~m}$. This leads to the following IHX characterization:

$\begin{array}{lll} & \text { ABC } & \text { MSBR } \\ \text { power, MW } & & \\ \text { central downcomer diameter, } \mathrm{m} & 375 & 556.3 \\ \text { tube length, m } & 0.4 & 0.508 \\ \text { number of tubes } & 3.5 & 7.44 \\ \text { tube diameter, in. } & 8315 & 5803 \\ \text { tube pitch, in. } & \text { same } & 0.375 \\ \text { shell diameter, m } & \text { same } & 0.75 \\ \text { overall height, m } & 2.0 & 1.717 \\ & 5.0 & 7.2 \\ \text { Tube side conditions } & & \\ \text { inlet temperature, }{ }^{\circ} \mathrm{F} & \text { fuel salt } & \text { fuel salt } \\ \text { outlet temperature, }{ }^{\circ} \mathrm{F} & 1300 & 1300 \\ \text { mass flow rate, } \mathrm{kg} / \mathrm{s}\left(\mathrm{lb} / \mathrm{hr} \times 10^{6}\right)^{6} & 1050 & 1050 \\ \text { Shell side conditions } & 1164(9.24) & 2955(23.4) \\ \text { inlet temperature, }{ }^{\circ} \mathrm{F} & \text { coolant salt } & \text { coolant salt } \\ \text { outlet temperature, }{ }^{\circ} \mathrm{F} & 850 & 850 \\ \text { mass flow rate, } \mathrm{kg} / \mathrm{s}\left(\mathrm{lb} / \mathrm{hr} \times 10^{6}\right)^{7} & 1150 & 1150 \\ & 1495(11.9) & 2218(17.6)\end{array}$

6 The MSBR flow rate cannot be scaled-down because the fuel salt for the $A B C$ is essentially LiF-BeF2 whereas the MSBR fuel salt is LiF-BeF2-ThF4-UF4.

7 Because the same coolant is used, the MSBR flow rates were scaled down to obtain the $A B C$ flow rates. 


\section{3 steam system}

The only available steam generator design data for a molten salt steam generator are those for the small $121 \mathrm{MW}$ horizontal U-tube, U-shell heat exchanger for the MSBR that employs a supercritical steam cycle with $1000^{\circ} \mathrm{F}$ steam at $3500 \mathrm{psia}$. The tube length for this steam generator is $23.29 \mathrm{~m}(76.4 \mathrm{ft})$, and the inner shell diameter is $0.464 \mathrm{~m}$ (18.25 inches). For illustration purposes this steam generator will be scaled up to $375 \mathrm{MW}$ but limiting the shell diameter to $1.50 \mathrm{~m}$.

Using the MSBR $121 \mathrm{MW}$ steam generator as reference, the total length of tubing for a $375 \mathrm{MW} A B C$ steam generator is:

$$
(375 / 121) \times 393 \times 23.29 \mathrm{~m}=28,366 \mathrm{~m} \text {. }
$$

The number of tubes that can be accommodated in a $1.5 \mathrm{~m}$ diameter shell in relation to the 393 tubes accommodated in the $0.464 \mathrm{~m}$ shell is:

$$
393 \times(1.5 / 0.464)^{2}=4115 \text { tubes. }
$$

The tube length for the $A B C$ steam generator is then:

$$
28,366 / 4115=6.893 \mathrm{~m} \text {. }
$$

The overall length of the steam generator has to account for the curvature and the height of the plena. The tube length consist of two straight sections and one curved section. Assuming an average curvature radius of $0.6 \mathrm{~m}$, the length of the straight sections is $2.5 \mathrm{~m}$, and the height of the bundle is $3.1 \mathrm{~m}$. Assuming a radius of 0.75 $\mathrm{m}$ for the inlet and outlet plena, respectively, yields an overall height for the steam generator of $4.6 \mathrm{~m}$.

For the supercritical steam cycle of the MSBR steam reheaters had been added which were sizeable structures (603 tubes, $13.2 \mathrm{ft}$ long tubes, shell ID of 20.25 inches, and overall height of $15 \mathrm{ft}$ ).

Using a different steam cycle without reheat requires a new design. It is proposed to look closer at a vertical U-tube design (like CANDU) that would include primary and secondary moisture separators and may yield a height of $15 \mathrm{~m}$ for the $A B C$ system. It is also proposed to evaluate a helical coil steam generators. 
The steam generator design and estimate of flow rates is fairly complex. To illustrate some of these difficulties properties of superheated steam at $900^{\circ} \mathrm{F}$ are cited for 2400 and 3500 psia.

2400 psia 3500 psia

Thermal conductivity, Btu/(hr-ft- F)

Viscosity, $\mathrm{lb} / \mathrm{ft}^{2} \times 10^{6}$

0.052

63

0.062

Specific volume, $\mathrm{ft}^{3} / \mathrm{lb}$

0.285

67

Specific heat, Btu/(lb- $\left.{ }^{\circ} \mathrm{F}\right)$

0.74

0.176

Relative film resistance to heat transfer

1.9

0.91

1.0

This illustrates why the high-pressure supercritical cycle has such an attraction from a heat transfer perspective. The film coefficient for heat transfer in the 3500 psia system is about twice that in the 2400 psia system and, therefore, the surface area required would be significantly less. 
TABLE 6: IHX FEATURES FOR THE MSBR AND CRBRP

\begin{tabular}{|c|c|c|}
\hline IHX FEATURES & MSBR & CRBRP \\
\hline $\begin{array}{l}\text { thermal duty, } \mathrm{MW} \\
\text { overall length, } \mathrm{ft} \\
\text { shell diameter, } \mathrm{ft} \\
\text { tube length, } \mathrm{ft} \\
\text { \# of tubes } \\
\text { overall heat transfer area, } \mathrm{ft}^{2} \\
\text { overall heat transfer coefficient, Btu/hr- } \mathrm{F}-\mathrm{ft}^{2} \\
\text { primary flow, } 10^{6} \mathrm{lb} / \mathrm{hr} \\
\text { intermediate flow, } 10^{6} \mathrm{lb} / \mathrm{hr} \\
\text { primary system } \\
\text { hot leg temperature, }{ }^{\circ} \mathrm{F} \\
\text { cold leg temperature, }{ }^{\circ} \mathrm{F} \\
\text { intermediate system } \\
\text { hot leg temperature, }{ }^{\circ} \mathrm{F} \\
\text { cold leg temperature, }{ }^{\circ} \mathrm{F}\end{array}$ & $\begin{array}{l}556.5 \\
24 \\
5.7 \\
24.4 \\
5803 \\
13,916 \\
784.8 \\
23.4 \\
17.8 \\
1300 \\
1050 \\
1150 \\
850 \\
\end{array}$ & $\begin{array}{l}325 \\
52.1 \\
8.8 \\
25.8 \\
2850 \\
11,810 \\
1,374 \\
13.82 \\
12.78 \\
995 \\
730 \\
936 \\
651\end{array}$ \\
\hline
\end{tabular}




\section{A3.0 Drawings for System and Component Layouts ${ }^{8}$}

A series of drawings has been prepared to better illustrate the $A B C$ system design concept.

Not addressed here are the accelerator-molten salt system interface and the accelerator with the target assembly. Cited often as a complication for an ABC system are the penetrations required for the beam tube and target assembly. However, the penetration through the vessel to install the target assembly is in principle not different from the penetrations required for control rods drive lines in a reactor.

What should help greatly in the design of the target assembly and especially the target window, as well as the seals for the penetrations is the very low operating pressure for the primary system. The primary system operating pressure is affected by two considerations, (1) the need for a high pressure to avoid fuel boiling, and (2) the primary system pressure drop.

Because the vapor pressure of molten salts is very low even at high temperatures, a pressurization of the primary system is not required to delay fuel boiling.

The pressure drop in the core and piping should be minimal. Assuming the same tubing dimensions and layout as in the MSBR IHX should more than cut in half the pressure drop in the IHX to less than 50 psi because the $A B C \mathrm{IHX}$ tubing is less than half the length for the MSBR IHX. Further reductions, if desired, can be obtained by opening up the pitch and increasing the tube diameter. Under those conditions it is conceivable that the primary system pressure is significantly less than 100 psia which greatly simplifies not only the target design but also the primary system design and should also result in significant cost savings.

These benefits, however, can only be realized if the secondary and steam system pressures are not excessively high so that any tube rupture in these two system does not lead to damage in the primary system. This is an illustration for the correctness of the safety-first design approach. The scope in the design has to cover not only success and reliability of operation under normal operating conditions, but also safety under accident conditions.

8 Extensive use will be made of the work reported in "Preconceptual ABC Design Definition and System Configuration Layout" and submitted to LANL in March 1995. 
Drawings for the blanket system, intermediate system, steam system, gas sparging system, off-gas system, fuel drainage system, containment system and overall plant layout have been prepared. The drawings are roughly on scale. At the preconceptual design level it was not considered meritorious to tie down dimensions to be within 10 or $20 \%$ of the final dimensions because not a single component has been designed yet.

Fig. 4 shows the flow sheet for the ABC NSSS. Fig. 5 shows schematically the heat transport system hydraulic profile with its staggered thermal centers.

\section{1 core}

Fig. 6 shows a schematic drawing of the $A B C$ blanket configuration/module in a reflected system. Cold fuel coming from the IHX enters, through the outer of two concentric pipes, the gap between core barrel and vessel, thus keeping both structures at inlet temperature. The fuel flows downward, passes through holes in the lower core support plate to enter the inlet plenum. From here the fuel flows upward through holes in the lower axial reflector/shield into the core region. The hot fuel proceeds through a gap formed by the radial reflector and the upper axial reflector/shield to the inner of the concentric pipes on its way to the IHX. Each of the modules has two outlet/inlet pipes. At the bottom of the vessel is a drainage hole that is kept closed by a freeze plug located underneath that is not shown in the figure.

\section{2 primary and intermediate system}

Fig. 7 shows the Inside of the primary system cell that contains the blanket module, two fuel pumps and two IHXs. To better illustrate the elevations and sizes of the components they were rotated such that a single train core-pump-IHX is visible. In reality, these components are not fully visible in a side view as shown in Fig. 18.

The arrangement is such that each component can be withdrawn from this cell in a straight-pull motion. Not shown is the draitiage line for the coolant from the IHX that facilitates complete drainage by gravity. Fuel drainage by gravity is complete and from the bottom drain line in the core vessel. The fuel pump is in the hot leg at the highest elevation. The fuel pump motor is located outside the containment. The fuel pump bowl is about $1.80 \mathrm{~m}$ in diameter. The concrete shielding surrounding the cell is about $2.50 \mathrm{~m}$ thick. This cell is a safety-related structure. The inside of this concrete structure contains a Hastelloy $\mathrm{N}$ (or steel) liner with insulation material between the liner and the concrete. The cavity is filled with NaF-LiF-BeF ${ }_{2}$ molten salt. Should NaF- 


\section{PRECONCEPTUAL ABC DESIGN DEFINITION AND SYSTEM CONFIGURATION LAYOUT}

$\mathrm{BeF}_{2}$ become the carrier salt for the fuel, it would be both coolant salt and also the salt in the cavity.

Fig. 8 shows the cell containing the IHTS isolation valves and the secondary (coolant salt) pump. It needs to be determined whether it is necessary to fill this cell with a salt like $\mathrm{NaF}_{-} \mathrm{BeF}_{2}$ to contain leaks, should there be any, and serve as a heat sink. The pump and IHTS valves can be removed from this cell in straight-pull motions.

Underneath this cell is a salt storage area that has not been specifically defined yet. This cell, like all the others is surrounded by a $2.5 \mathrm{~m}$ thick concrete wall. It is a safety-related structure. The walls are stainless-steel-clad and heavily insulated. Should the cell be filled with salt, the use of Hastelloy $\mathbf{N}$ will be considered.

On top of the primary and secondary system cell and the IHTS and coolant pump cell is a containment building that contains maintenance enclosures and a polar crane together with an auxiliary crane.

\section{3 steam system}

The steam system is schematically shown in Fig. 9. The steam generator, a drain tank, and a set of MSIV are contained in a separate containment that has $2.5 \mathrm{~m}$ thick walls. It is a safety-related structure. Next to this containment building is the feedwater heating bay that contains another set of MSIV and feedwater heating equipment. The Feedwater Heating Bay is built to high industry standards. It is not a safety-related structure.

It needs to be determined whether another set of isolation devices is required to protect the IHX in case of a steam generator tube rupture. The MSBR used rupture disks that were located at the secondary-salt outlet of each steam generator. Furthermore, quick-acting block valves at the inlet and outlet of each steam generator were used to isolate the steam generator.

At present, one set of MSIV is placed inside the steam generator cell, and another set is located in the feedwater bay area. This might very well be an overdesign where one set of valves could be saved. The intent here was to provide a very high reliability through redundancy to isolate the steam generator to significantly lower the probability that radionuclides could leak from the primary system into the secondary system, from there into the steam system and ultimately the into the feedwater bay area. 
On top of the steam generator cell is the steam generator bay that provides a work area for the components inside the steam generator cell.

\section{4 gas sparging system}

Fig. 10 shows a schematic flow diagram for a gas sparging system, including both the bubble generation and removal bypass. This figure describes the MSBR system as shown in Fig. 3.37 of ORNL-4541. Because gas sparging has less importance for the $A B C$ system than the MSBR, a less complex system can most likely be used for the $A B C$ system.

\section{5 off-gas system}

Fig. 11 shows a schematic flow diagram of the MSBR off-gas system, as shown in Fig. 7.1 of ORNL-4541. Several options were considered for the ABC system. Option 1 shown in Fig. 12 eliminates the bubble generator system and the long-delay $\mathrm{Xe}$ holdup beds. The off-gas leaves the pump bowl through an entrainment separator and proceeds to the fuel drain tank. After a $2 \mathrm{hr}$ holdup, the off-gas enters the 47-hr Xe holdup system and then returns through a chemical trap and monitor to the primary system.

Fig. 13 shows a second option that maintains the bubble generator system shown in Fig. 11 but eliminates the long-term Xe holdup. After the gases leave the fuel salt drain tank they pass through a filter to remove particulate matters. After the 47-hr holdup all gases are returned to the primary system.

Fig. 14 shows the recommended off-gas system. It is very similar to option 2 shown in Fig. 13 but eliminates the particle trap and leaves open the holdup times in the fuel drain tank and in the Xe holdup system.

Fig. 15 shows a cross section of one bank of Xe holdup charcoal beds similar to the MSBR. Hairpin tubes are filled with charcoal through which the off-gases are directed. The heat is rejected to water that converts to $230 \mathrm{~F}$ steam which is condensed in a condenser and the condensate is directed back into the holdup bed. 


\section{6 fuel drainage system}

Fig. 16 shows a schematic flow diagram for the $A B C$ primary drain and heat removal system using $\mathrm{NaF}-\mathrm{BeF}_{2}$ - LiF as coolant. The decay heat produced in the fuel drain tank is passively removed by a coolant salt and transported to a water-salt heat exchanger. The heated water is transported passively to a water-air heat exchanger located in a heat reject stack.

In case $\mathrm{NaK}$ is used as coolant in the fuel drain tank, the ultimate heat sink, according to a design study for the MSBR could be a water tank where, not unlike in case of the charcoal beds, water is brought to a boil and then either returned after passing through a condenser, or released to the outside and makeup water is supplied.

\section{7 containment system}

The containment system is shown in Figs. 17 and 18. Fig. 17 shows the relation to each other of the mainline systems. To show core vessel, pump and IHXs, those components had to be rotated out of their position because otherwise they would not have been all visible. Fig. 18 shows a top view of the mainline systems. The dimensions are:

$\begin{array}{ll}\text { core vessel diameter: } & 4.80 \mathrm{~m} \\ \text { core diameter: } & 2.10 \mathrm{~m} \\ \text { reflector thickness: } & 1.25 \mathrm{~m} \\ \text { IHX vessel diameter: } & 2.00 \mathrm{~m} \\ \text { pump bowl diameter: } & 1.80 \mathrm{~m} \\ \text { containment wall diameter: } & 2.50 \mathrm{~m} \\ \text { approximate primary cell outer diameter: } & 16 \mathrm{~m} \\ \text { approximate primary cell inner diameter: } & 11 \mathrm{~m} \\ \text { approximate primary cell height: } & 9 \mathrm{~m} \\ \text { approximate building height on top of cells: } 12 \mathrm{~m}\end{array}$

At this stage of the $A B C$ design development no attempt was made to optimize the design and layout. Basic design analyses and decisions still have to be made that will affect the sizing of the cells and perhaps even their relationship to each other, as well as permissible module size, power density and system requirements. It is most likely that the reactor building wall thicknesses (the structure on top of the cells) can be significantly reduced, perhaps even to less than the MSBR building dome/wall thickness that was $3.5 \mathrm{ft}$. Inside the concrete building structure is a $1 \mathrm{~cm}$ thick liner made of carbon steel which acts as a sealing membrane to permit the achievement of 
less than one inventory loss per year. (The requirement for the MSBR was $0.1 \%$ per 24-hr period. A confinement building such as that proposed for the MHTGR had an expected leakage rate of one inventory per day).

It should be noted that none of the cell or building dimensions are excessive. For example, the MSBR reactor cell (inner) diameter was $22 \mathrm{~m}$ which is twice the diameter for the ABC cell. All MSBR structures were above ground with a containment building height of $57 \mathrm{~m}$. The total height above ground for the $A B C$ containment building can be less than $8 \mathrm{~m}$.

It is assumed that the accelerator beam will enter the reactor building below grade. How far below grade it has to be directed has to be based on well-justified requirements because it will affect building cost.

The primary system cell and the cell containing the IHTS isolation valves and coolant pumps are under the primary and secondary system containment bay which is another containment structure. On top of the two cells is a maintenance enclosure. This enclosure is a thin-walled containment vessel designed primarily to contain airborne contaminants during maintenance operations. It has access ports over the vessel, pumps and $\mathrm{IHXs}$.

As shown in Fig. 18, the primary system cell, IHTS-coolant pump cell and steam generator cell are safety-related structures. The feedwater heater bay requirement is to be built in accordance with high quality industrial staridards.

\section{8 overall plânt layout}

Fig. 17 and 18 already showed a single train configuration. Fig. 19 shows how two modules will share one off-gas system and one fuel drain system. Off-gas system and fuel drain system are placed next to each other. Shown is also the stack area assuming the coolant in the drain system is a molten salt.

No attempts was made at this stage of the design development to show hot cells, offices, areas for salt processing and storage, etc. These are not critical areas in regard to design viability albeit the cost for these facilities is not insignificant. 
A4.0 Impact of Power Density and Module Power on Containment Size

To assess the impact of changes in power density, power level and also height-todiameter (L/D) ratio, parametric studies were done with the following assumptions:

power density varies between $75-300 \mathrm{~kW} / \mathrm{I}$

module power was varied between 500 and $1000 \mathrm{MWt}$

L/D ratio was varied between 0.6 to 1.3

reflector thickness of $125 \mathrm{~cm}$

core barrel thickness of $2 \mathrm{~cm}$

gap between barrel and vessel wall of $4 \mathrm{~cm}$

vessel thickness of $3 \mathrm{~cm}$

\section{1 impact of power density}

Fig. 20 shows the relationship between power density and vessel diameter assuming a $750 \mathrm{MWt}$ module power level and an L/D ratio of 1.0. Increasing the power density by $400 \%$ decreases the vessel diameter by less than $20 \%$. Increasing the power density from $100 \mathrm{~kW} / \mathrm{l}$ to $150 \mathrm{~kW} / \mathrm{l}$ decreases the vessel size from $4.80 \mathrm{~m}$ to $4.53 \mathrm{~m}$, or by $27 \mathrm{~cm}$.

This is too small a change to be reflected in the containment size.

\section{2 impact of module size}

Fig. 21 shows the relationship between vessel diameter and power level assuming a power density of $100 \mathrm{~kW} / \mathrm{l}$ and an L/D ratio of 1.0 . Doubling the module power level increases the vessel diameter from $4.53 \mathrm{~m}$ at $500 \mathrm{MWt}$ to $5.01 \mathrm{~m}$ at $1000 \mathrm{MWt}$. Going from $750 \mathrm{MWt}$ to $1000 \mathrm{MWt}$ in module power increases the vessel diameter from $4.80 \mathrm{~m}$ to $5.01 \mathrm{~m}$, or by a mere $21 \mathrm{~cm}$.

This is too small a change to be reflected in the containment size.

\section{3 impact of $L / D$ ratio}

Fig. 22 show the relationship between vessel diameter and $L / D$ ratio, assuming a module power of $750 \mathrm{MWt}$ and a power density of $100 \mathrm{~kW} / \mathrm{l}$. Flattening the core from an L/D os 1.0 to an L/D value of 0.6 increases the vessel diameter from $4.80 \mathrm{~m}$ 
to $5.19 \mathrm{~m}$, or by $39 \mathrm{~cm}$. Increasing the core height so that the L/D ratio increases from 1.0 to 1.3 , decreases the vessel diameter from $4.80 \mathrm{~m}$ to $4.62 \mathrm{~m}$.

These changes are too small to be reflected in the containment size. This means that the L/D ratio should be determined largely based on physics considerations. 


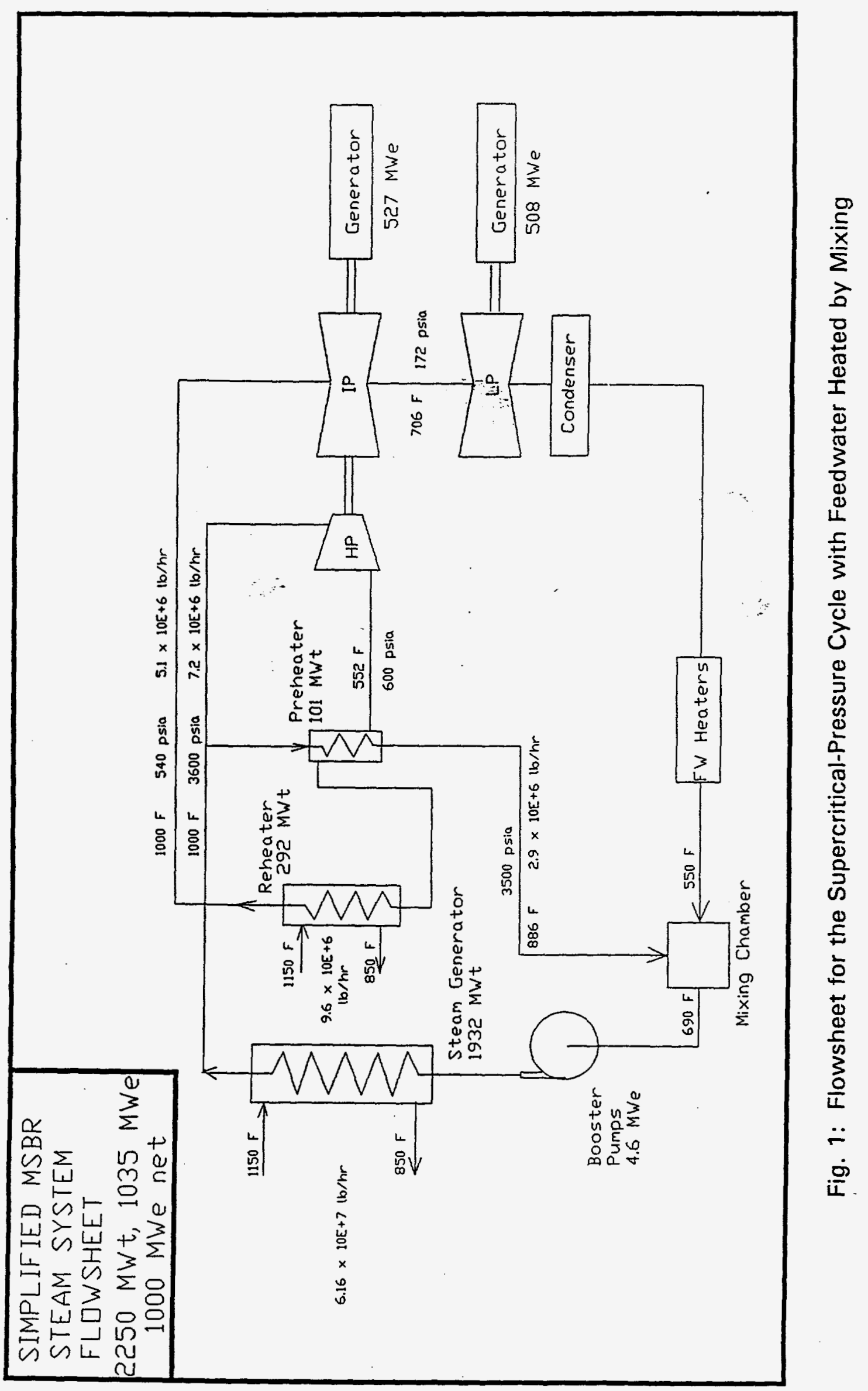




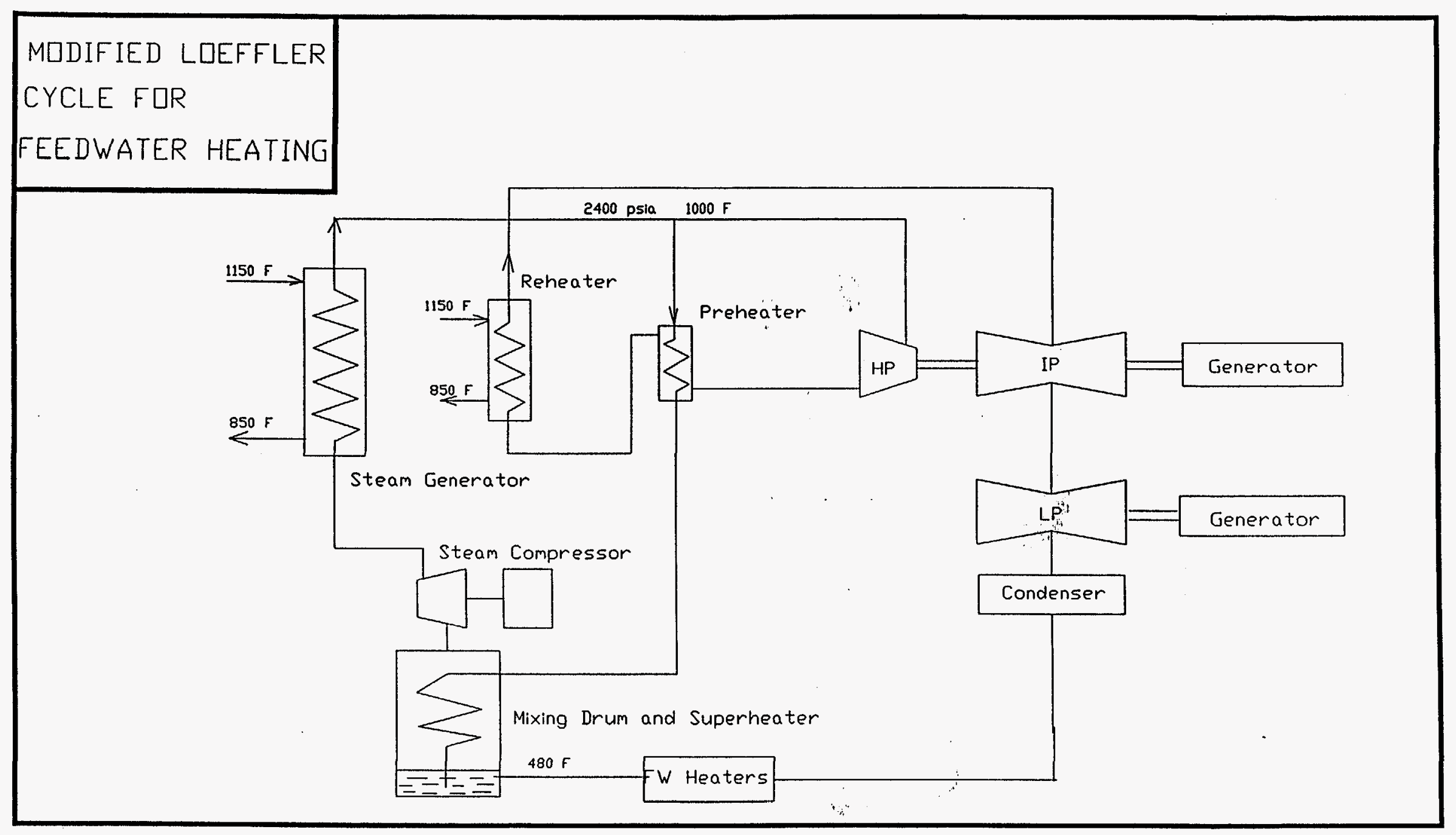

Fig. 2: Modified Loeffler Cycle for Feedwater Heating 
Fig. 3: Vertical U-Tube Steam Generator Similar to CANDU

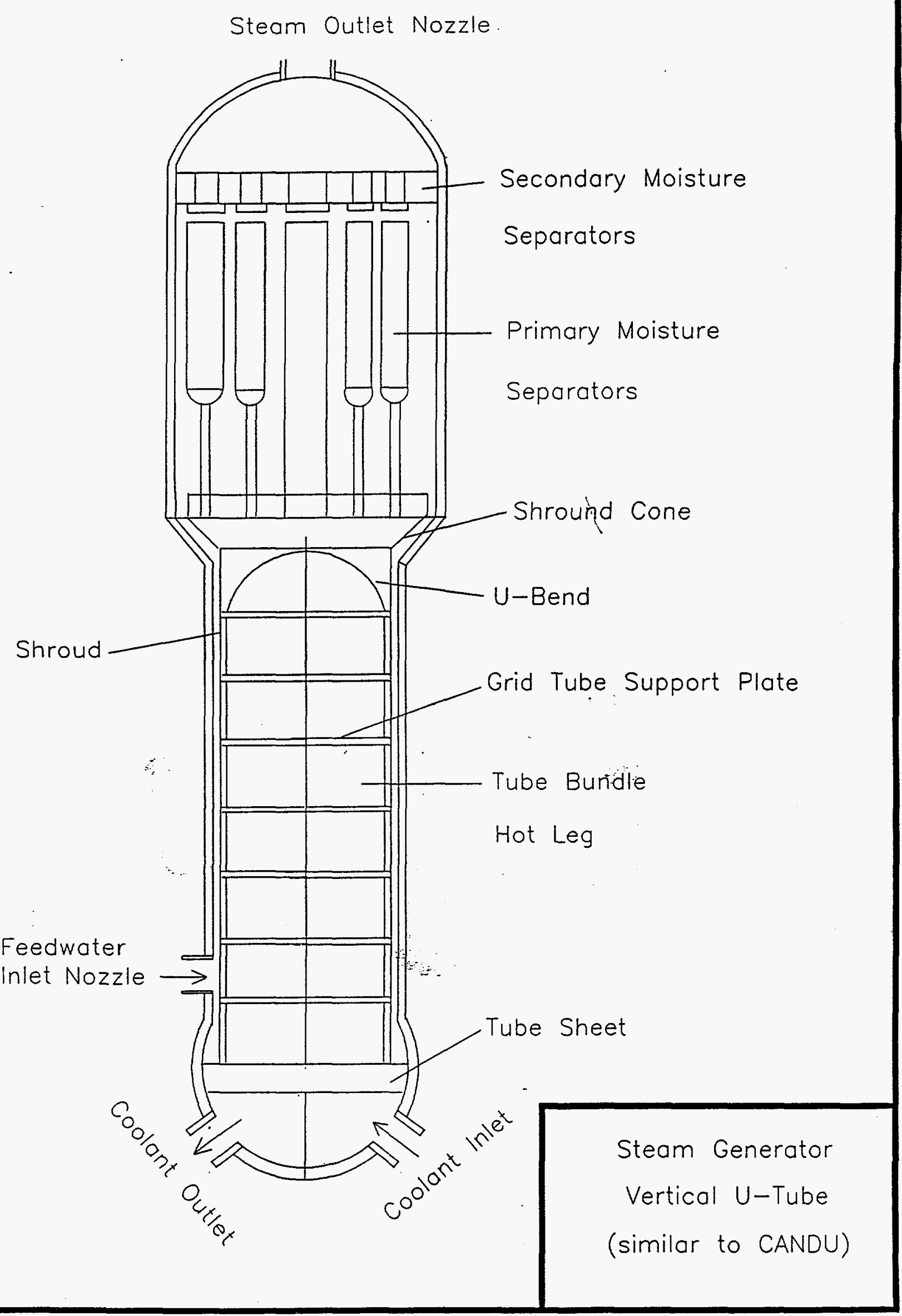




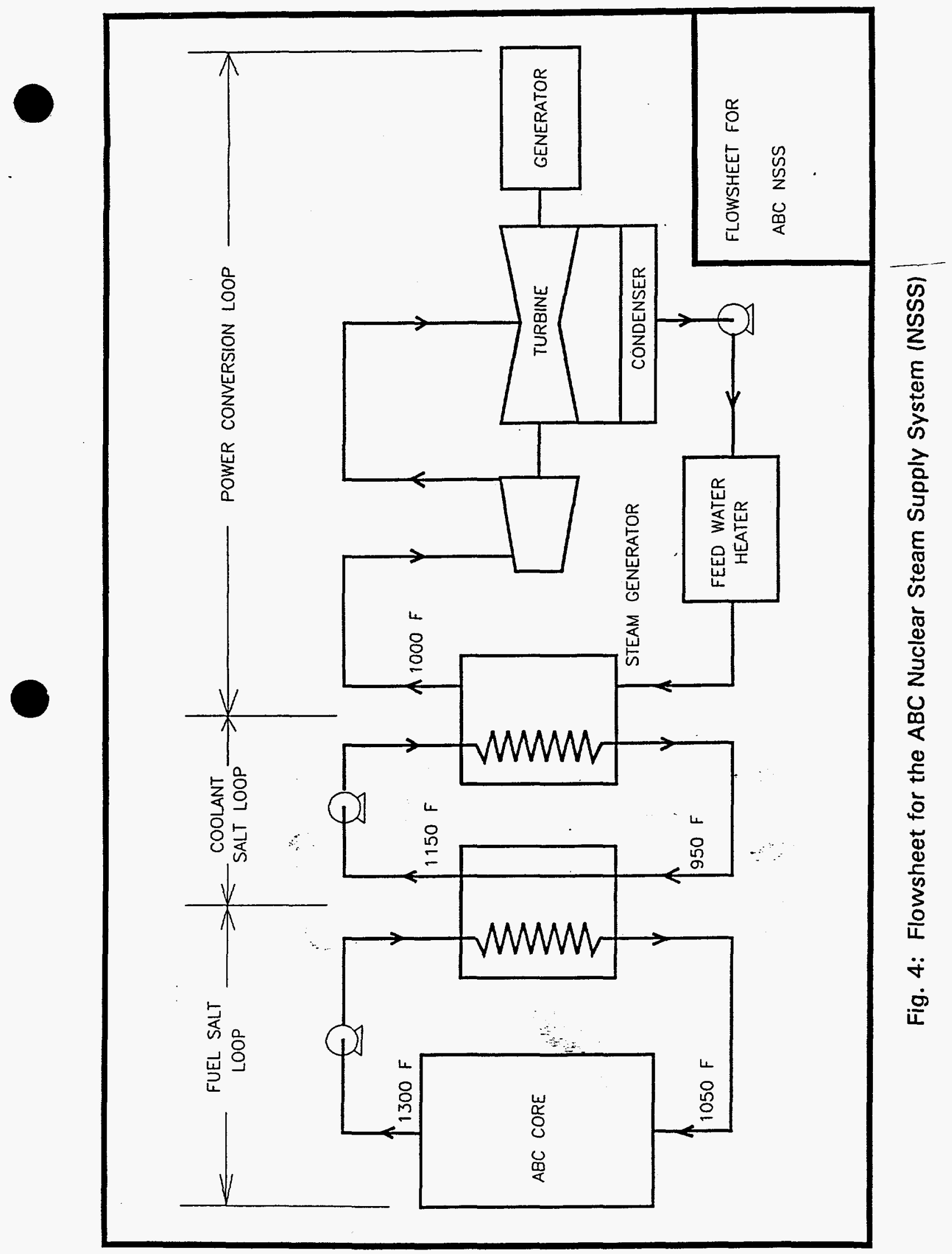




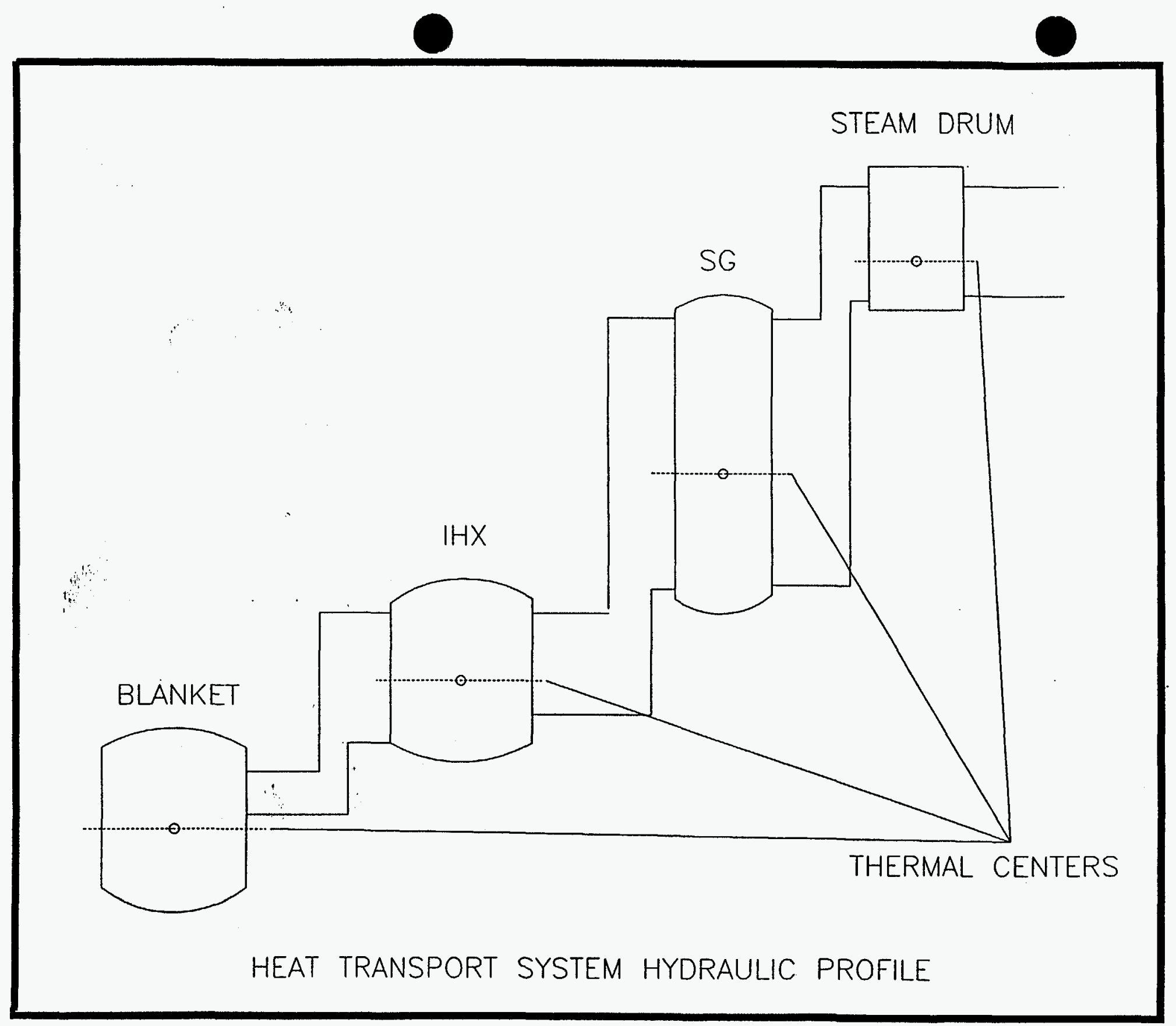

Fig. 5: Heat Transport System Hydraulic Profile 


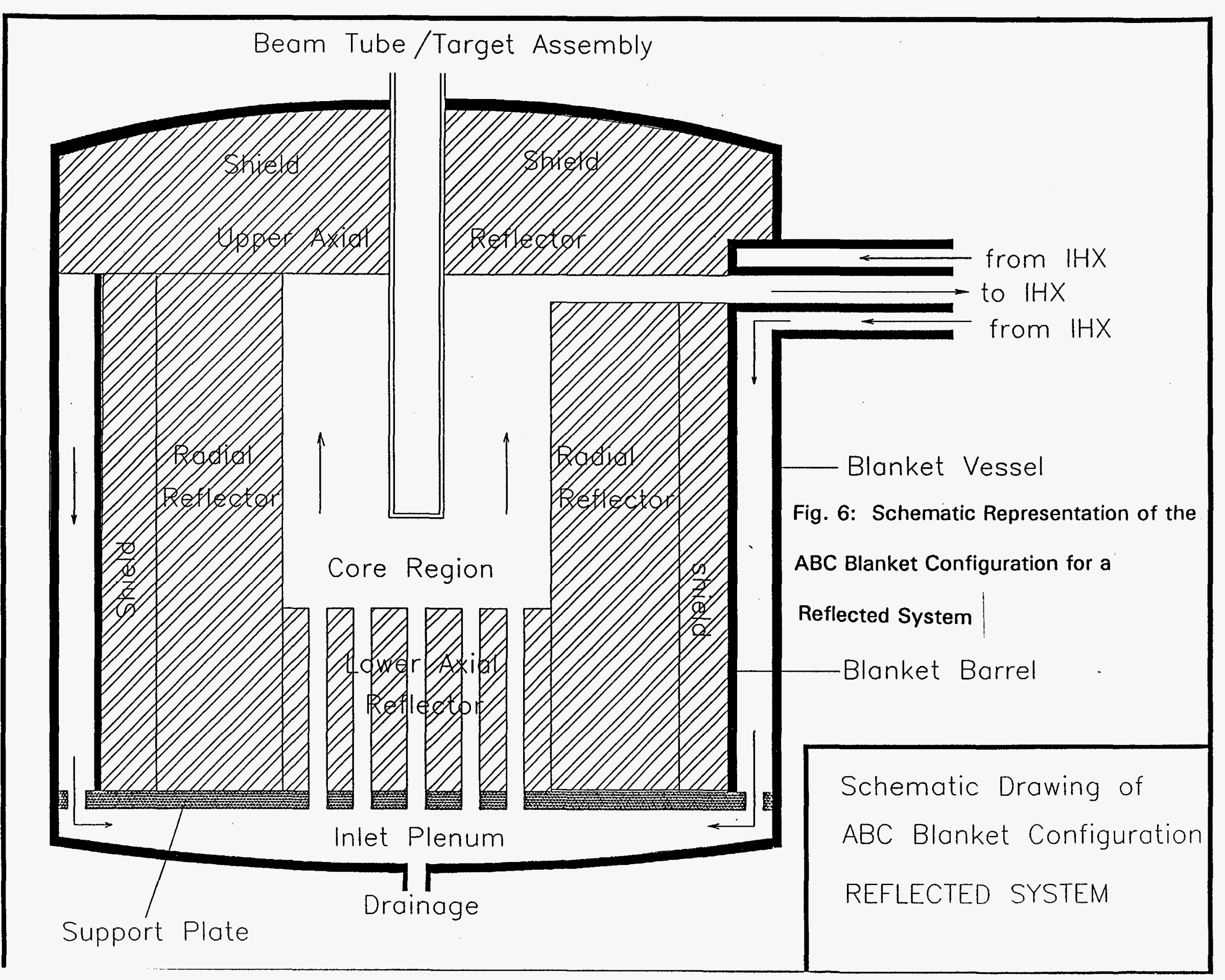




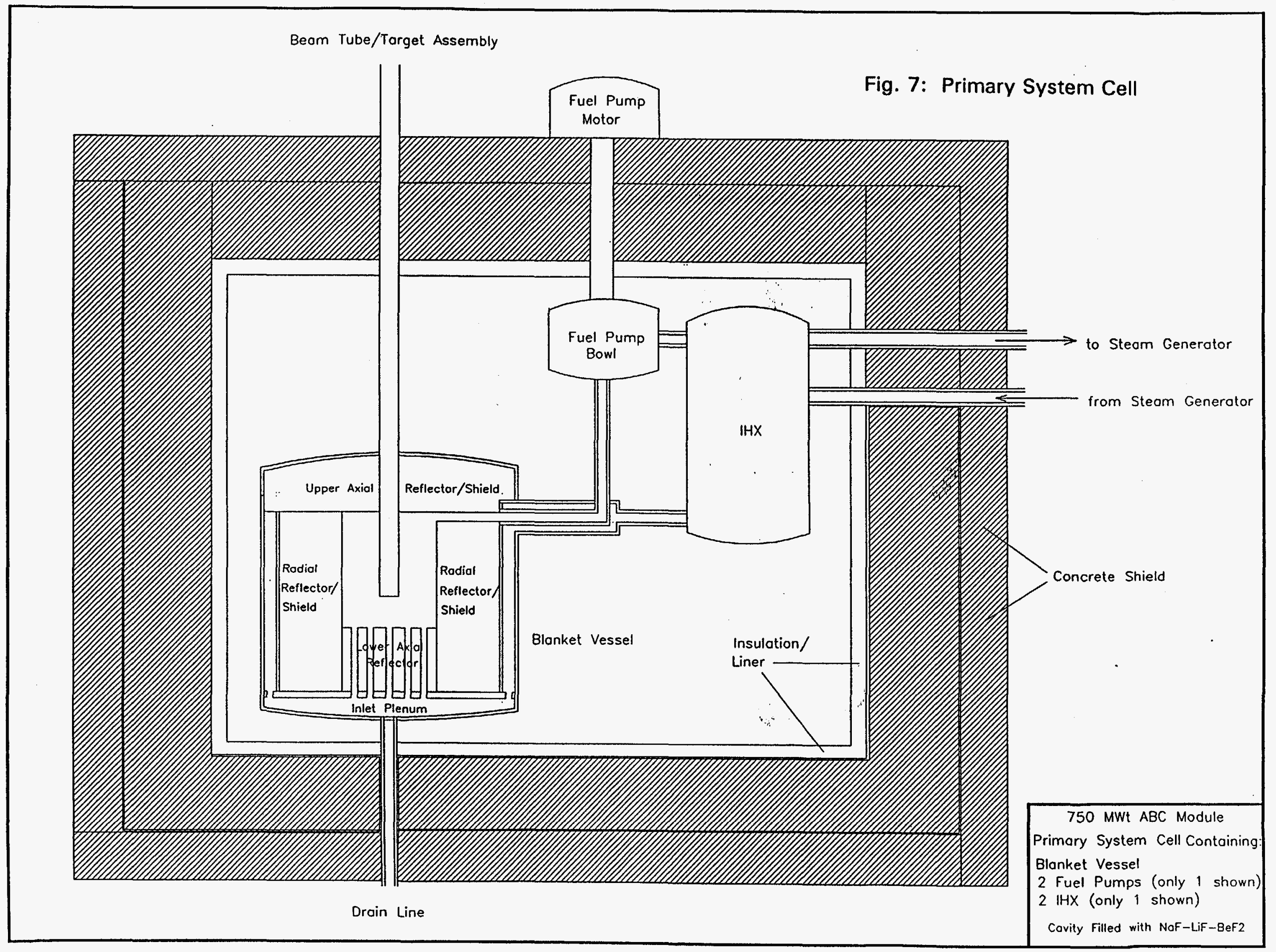




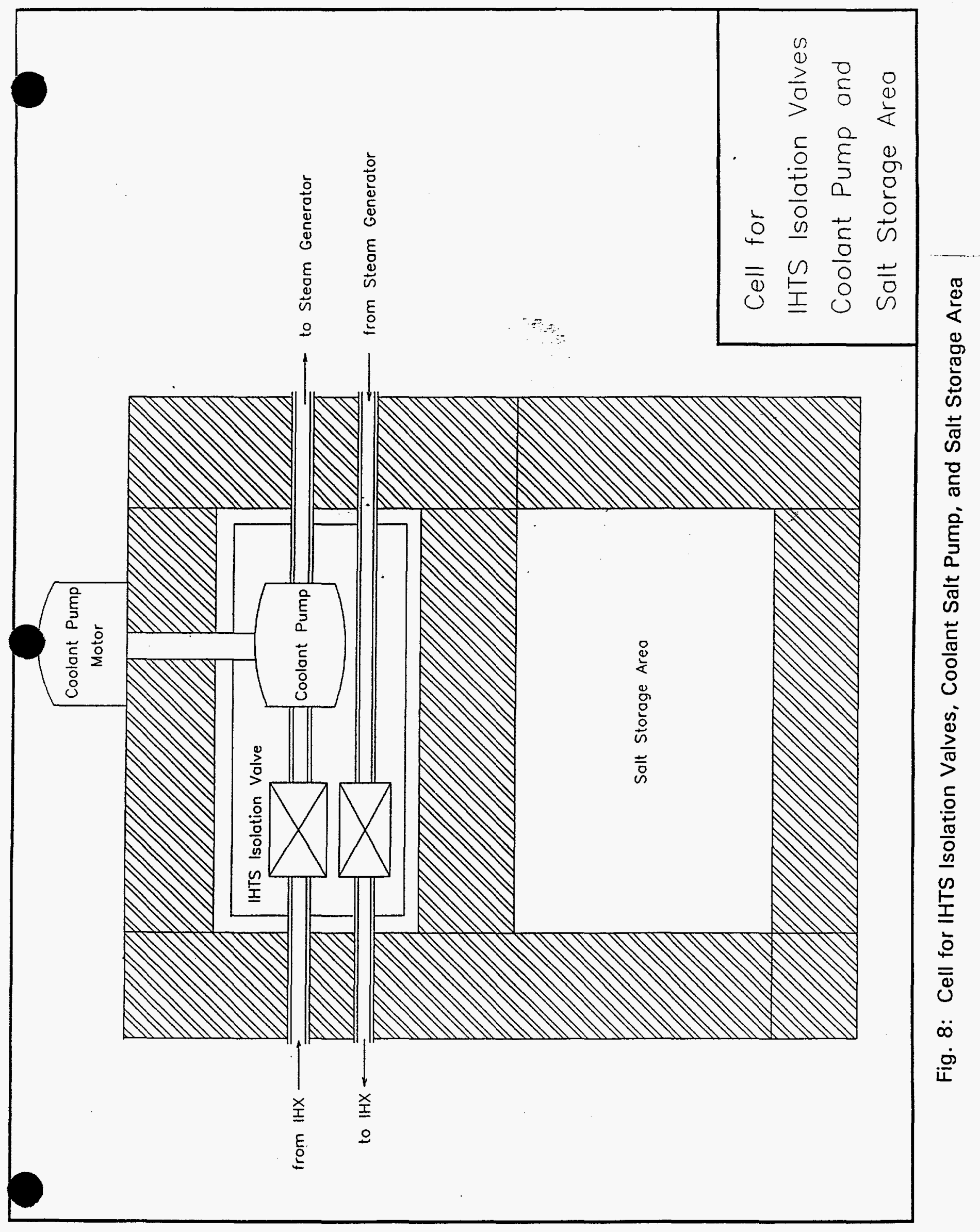




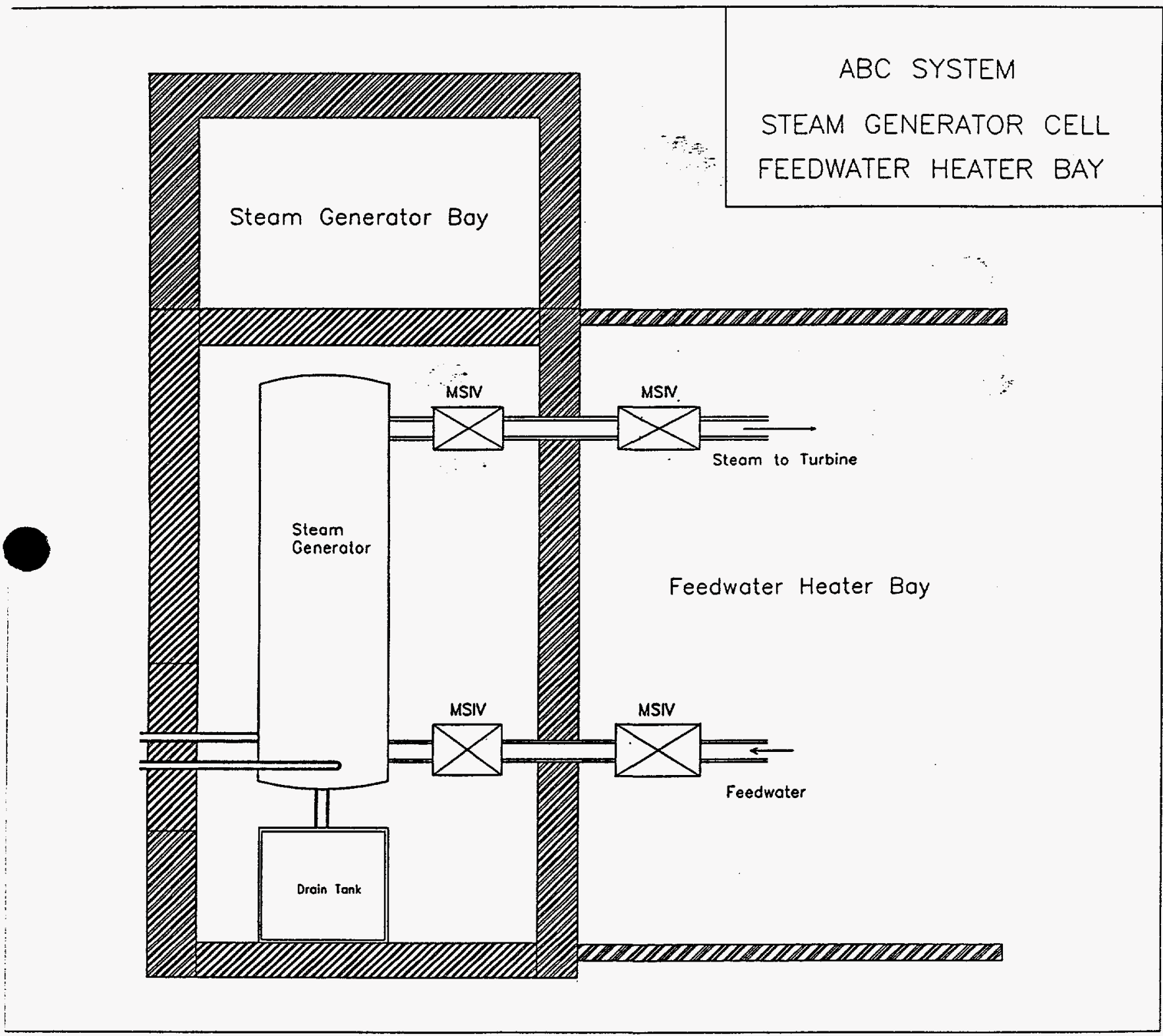

Fig. 9: Steam Generator Cell and Feedwater Bay 


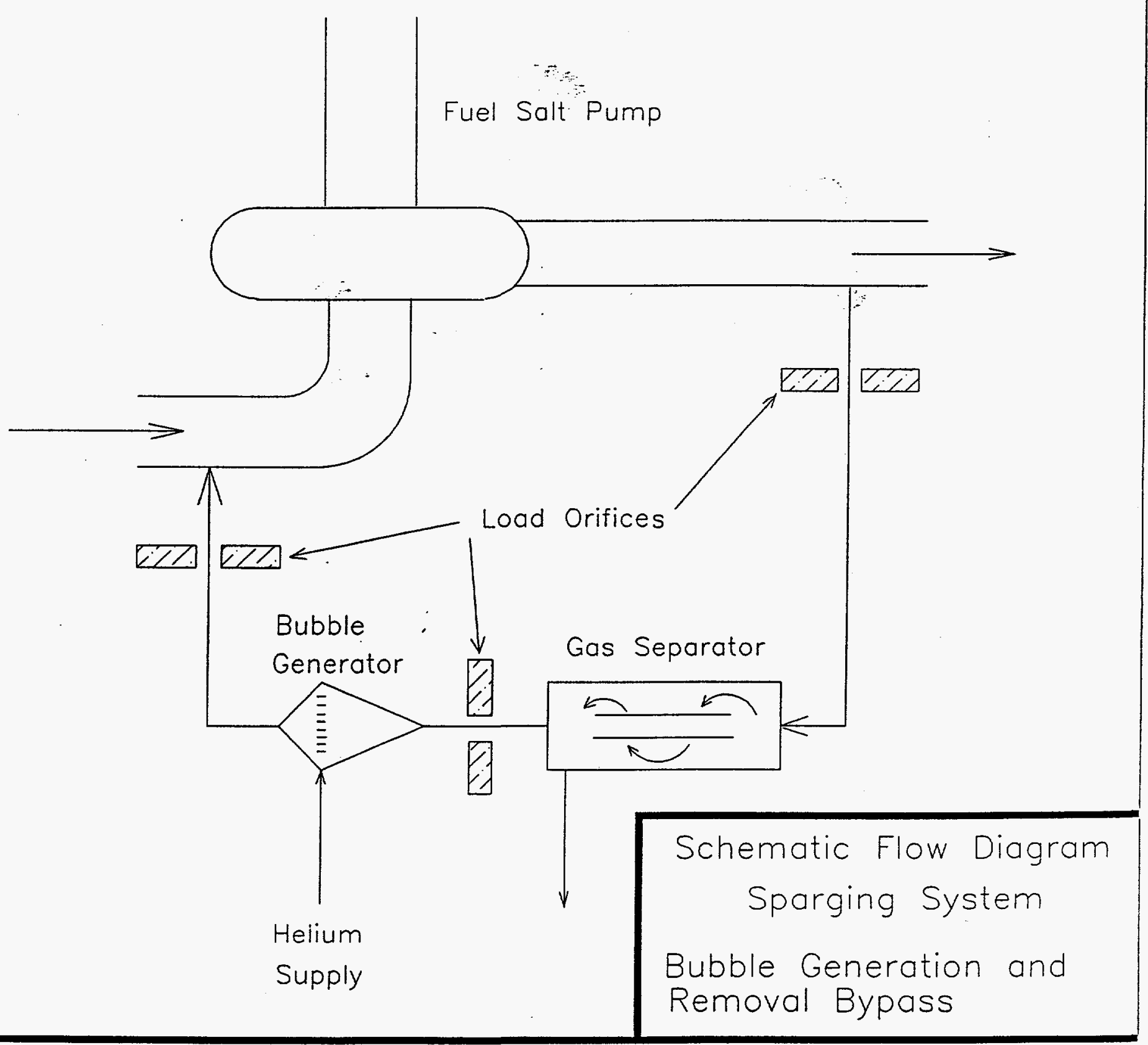

Fig. 10: Schematic Flow Diagram for the Sparging System 


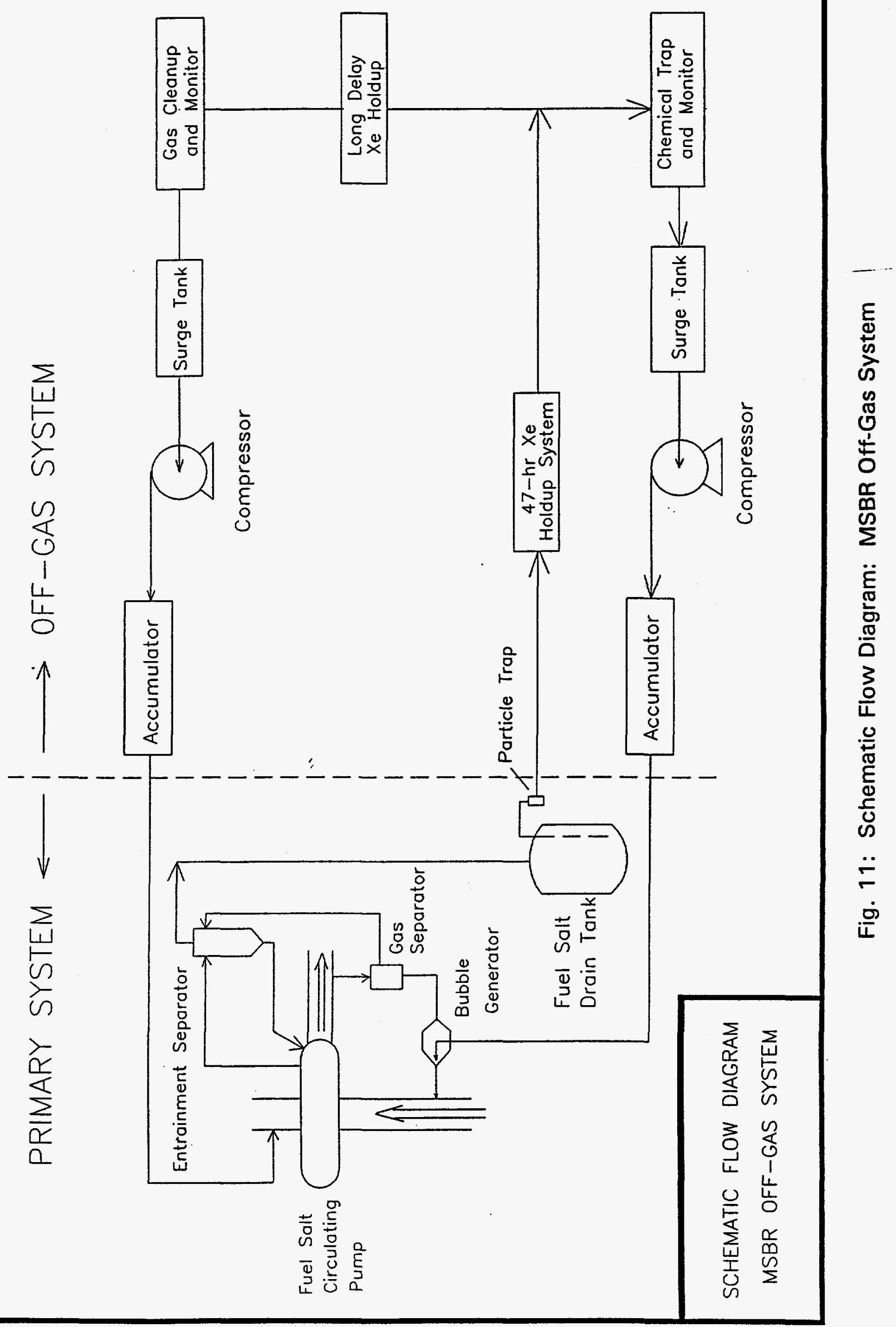




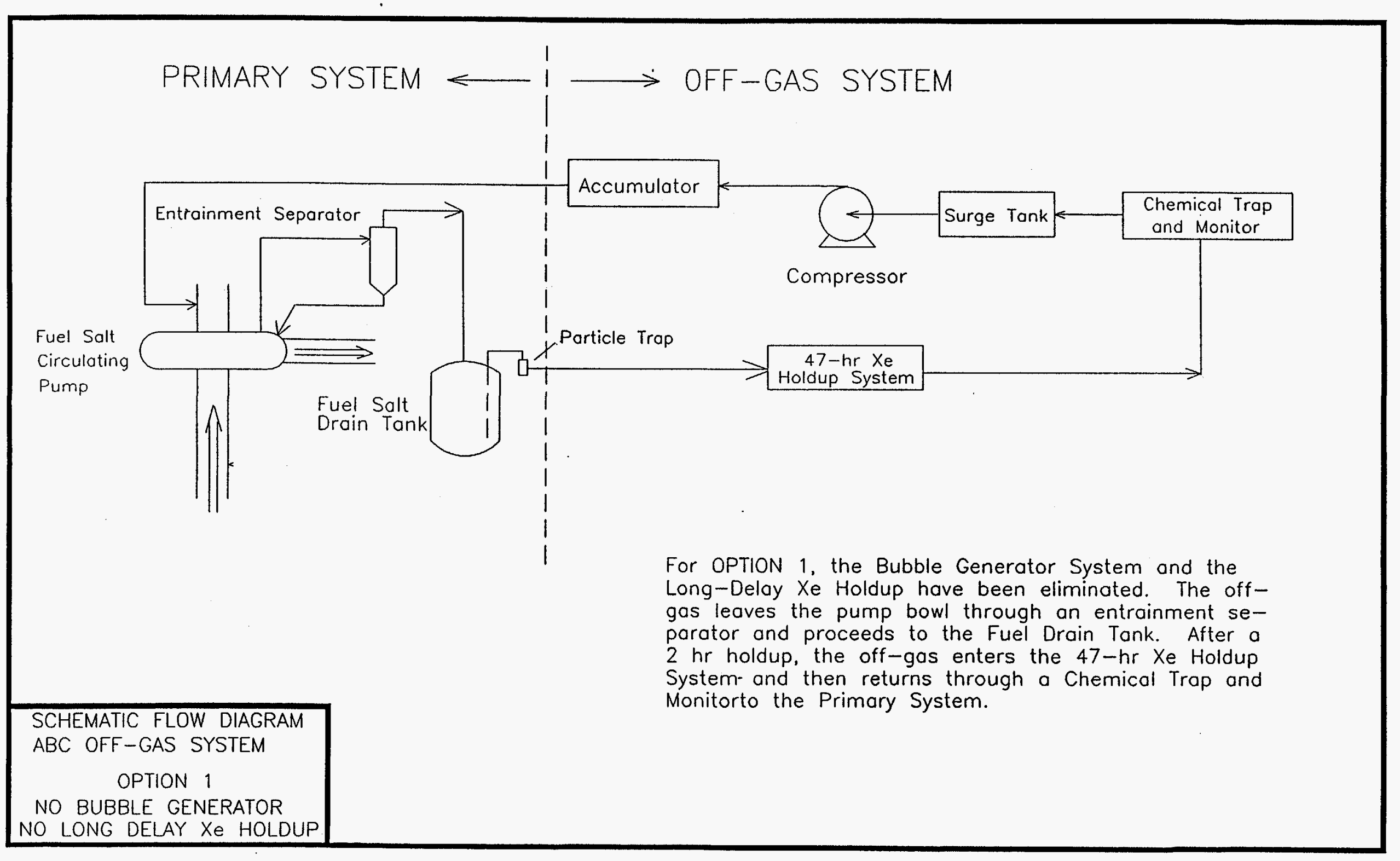

Fig. 12: Schematic Flow Diagram for the Off-Gas System: Option 1 


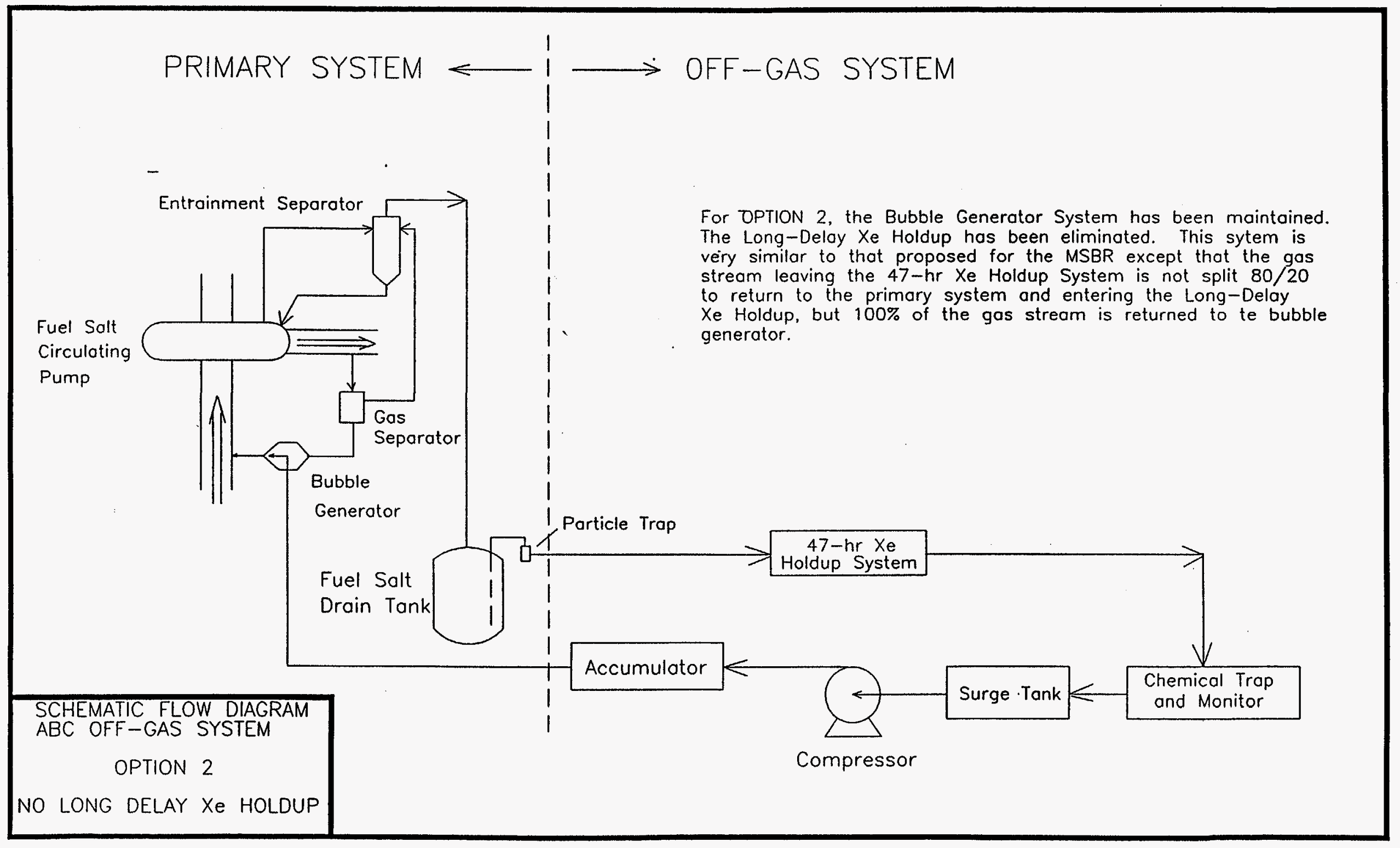

Fig. 13: Schematic Flow Diagram for the Off-Gas System: Option 2 


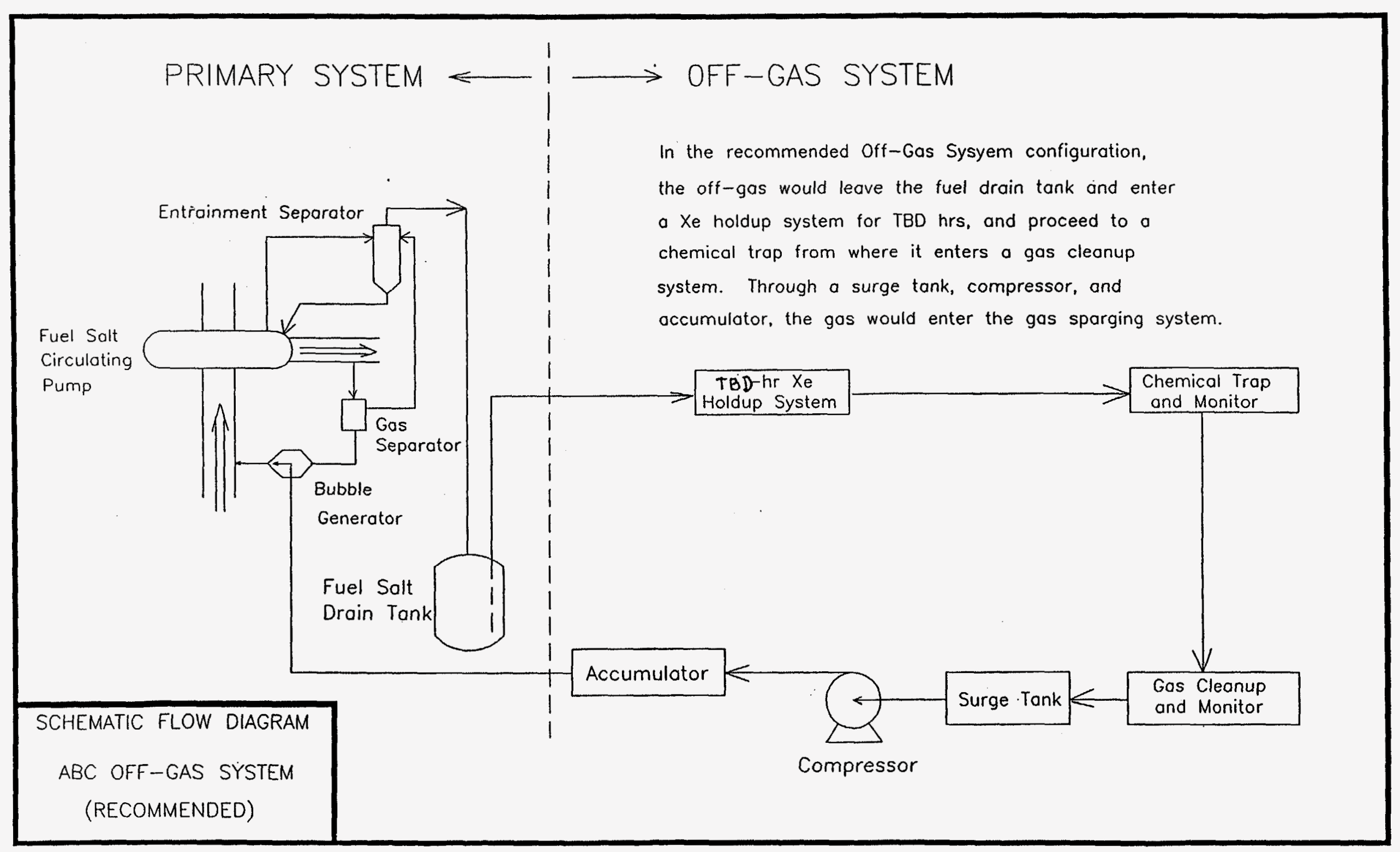

Fig. 14: Schematic Flow Diagram for the Recommended ABC Off-Gas System 


\section{ABC OFF-GAS SYSTEM}

Cross Section of one Bank of 47-hr Xe Holdup Charcoal Bed Similar to MSBR

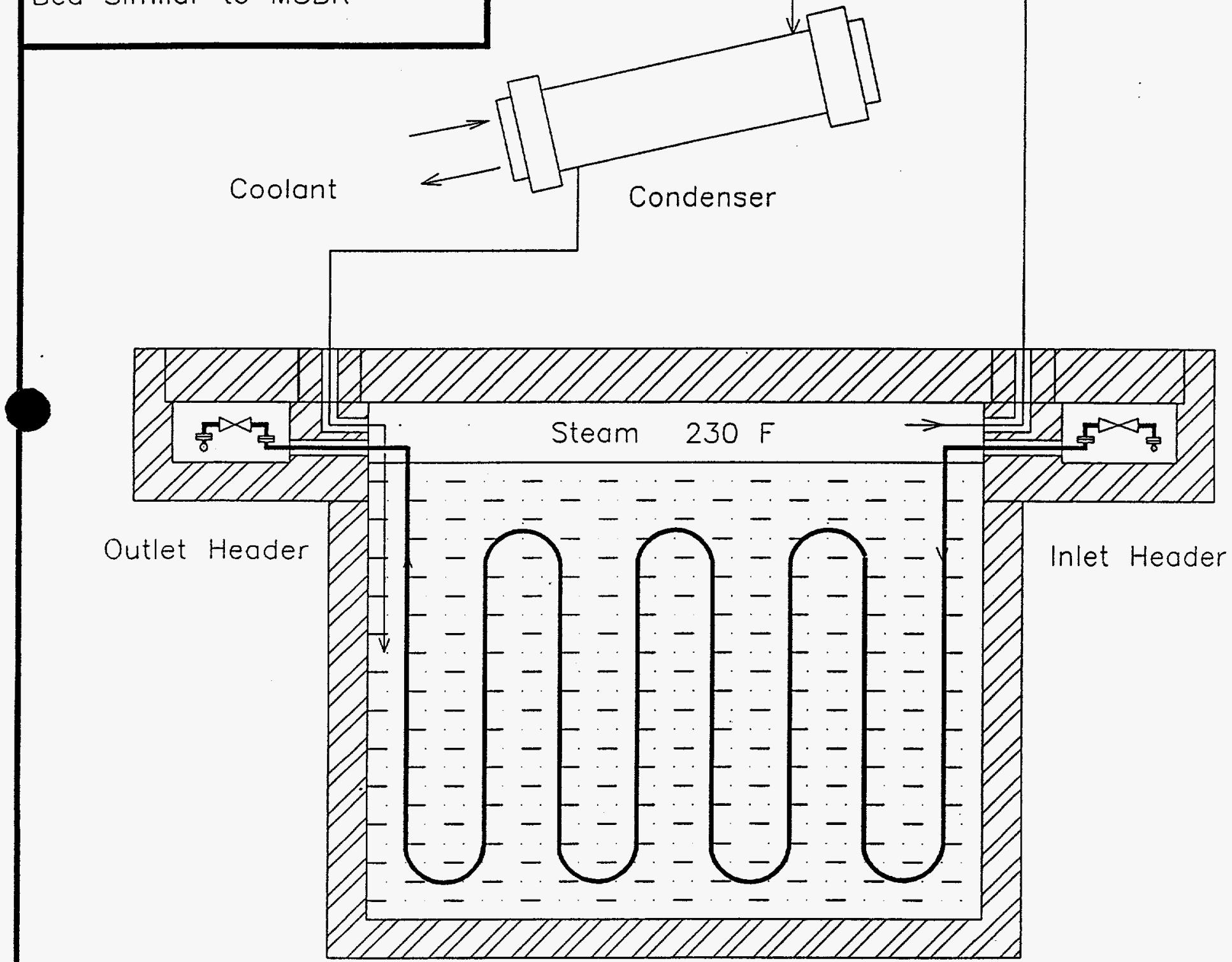

Fig. 15: Off-Gas System Charcoal Bed 


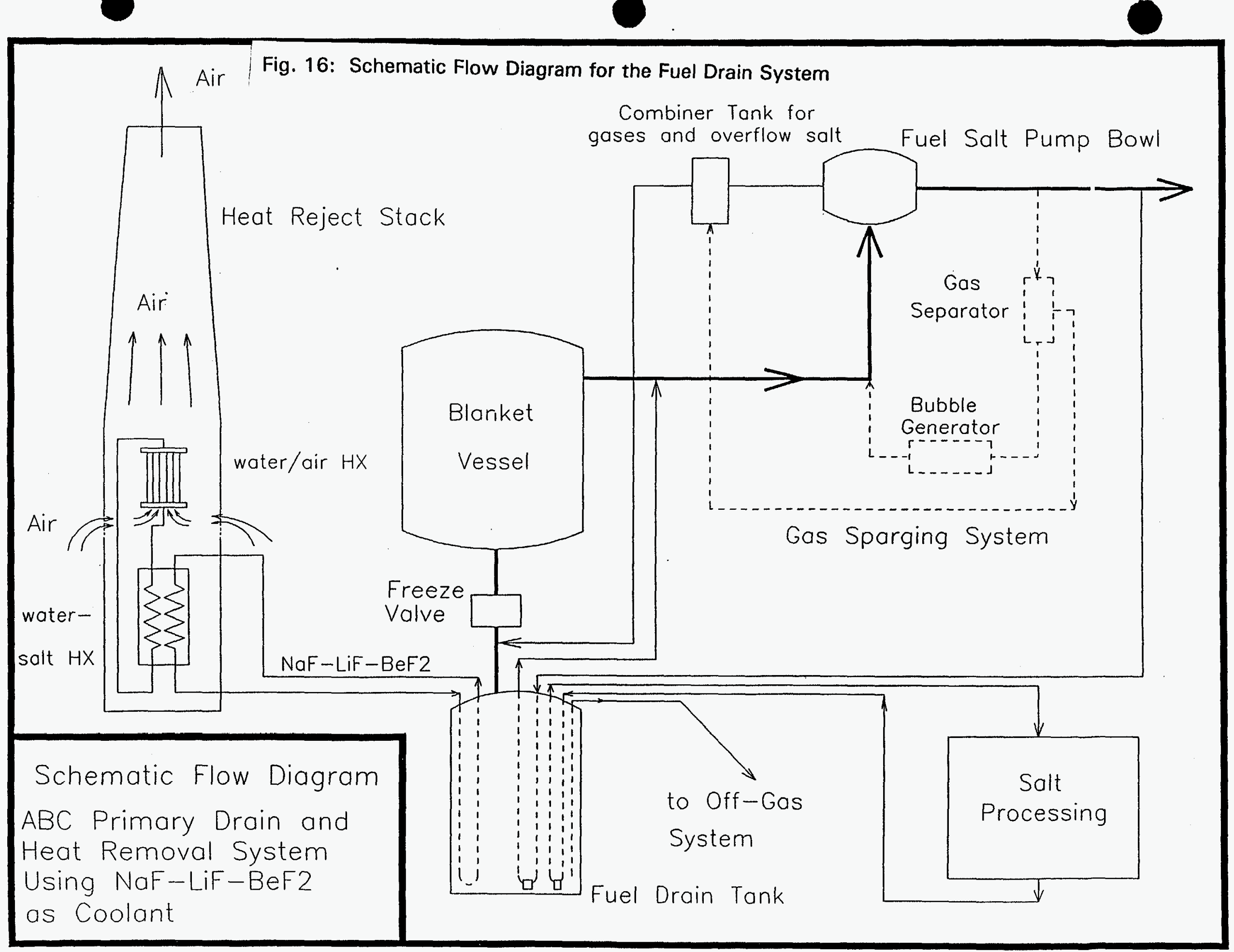




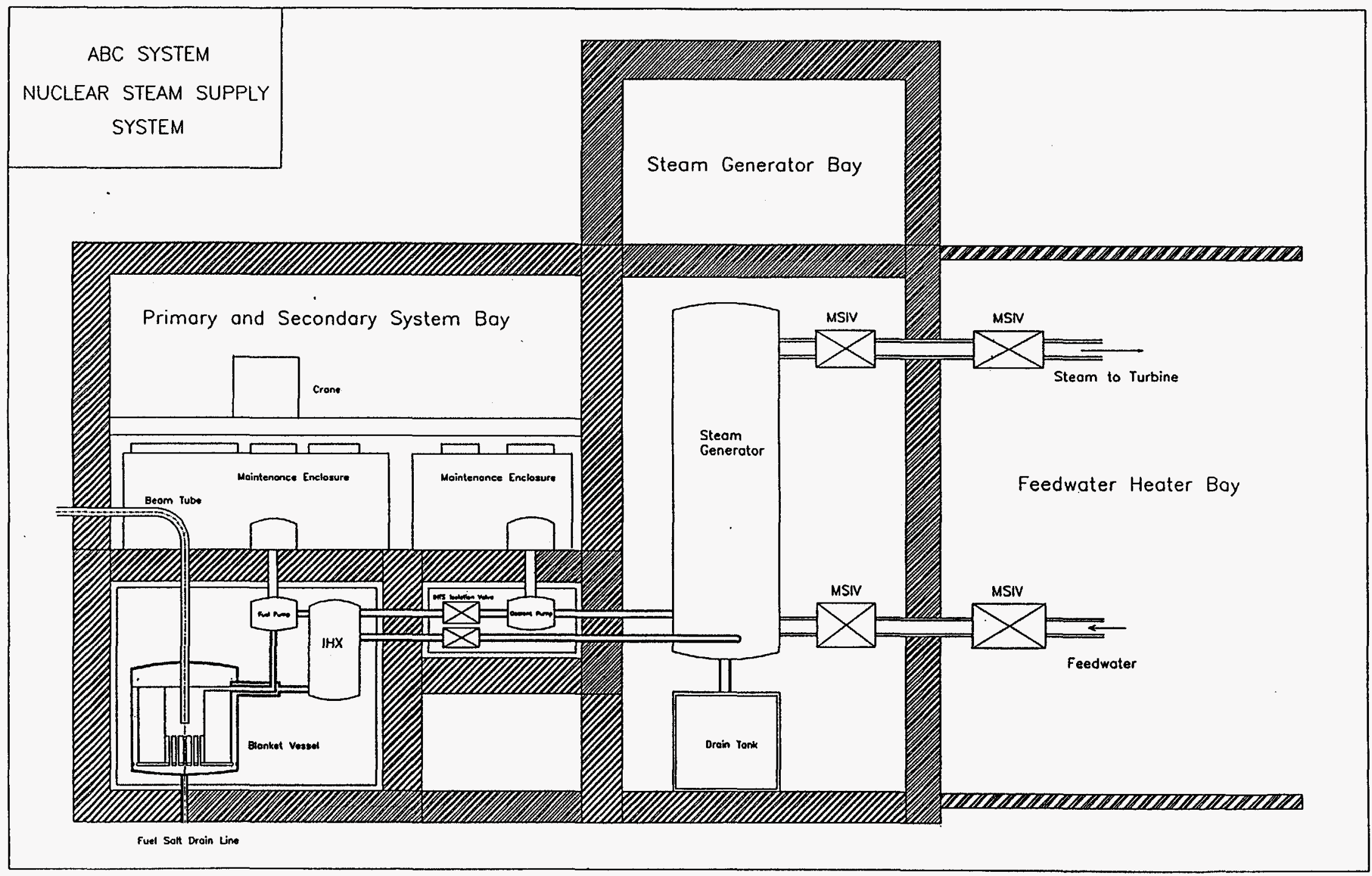

Fig. 17: ABC System Nuclear Steam Supply System 


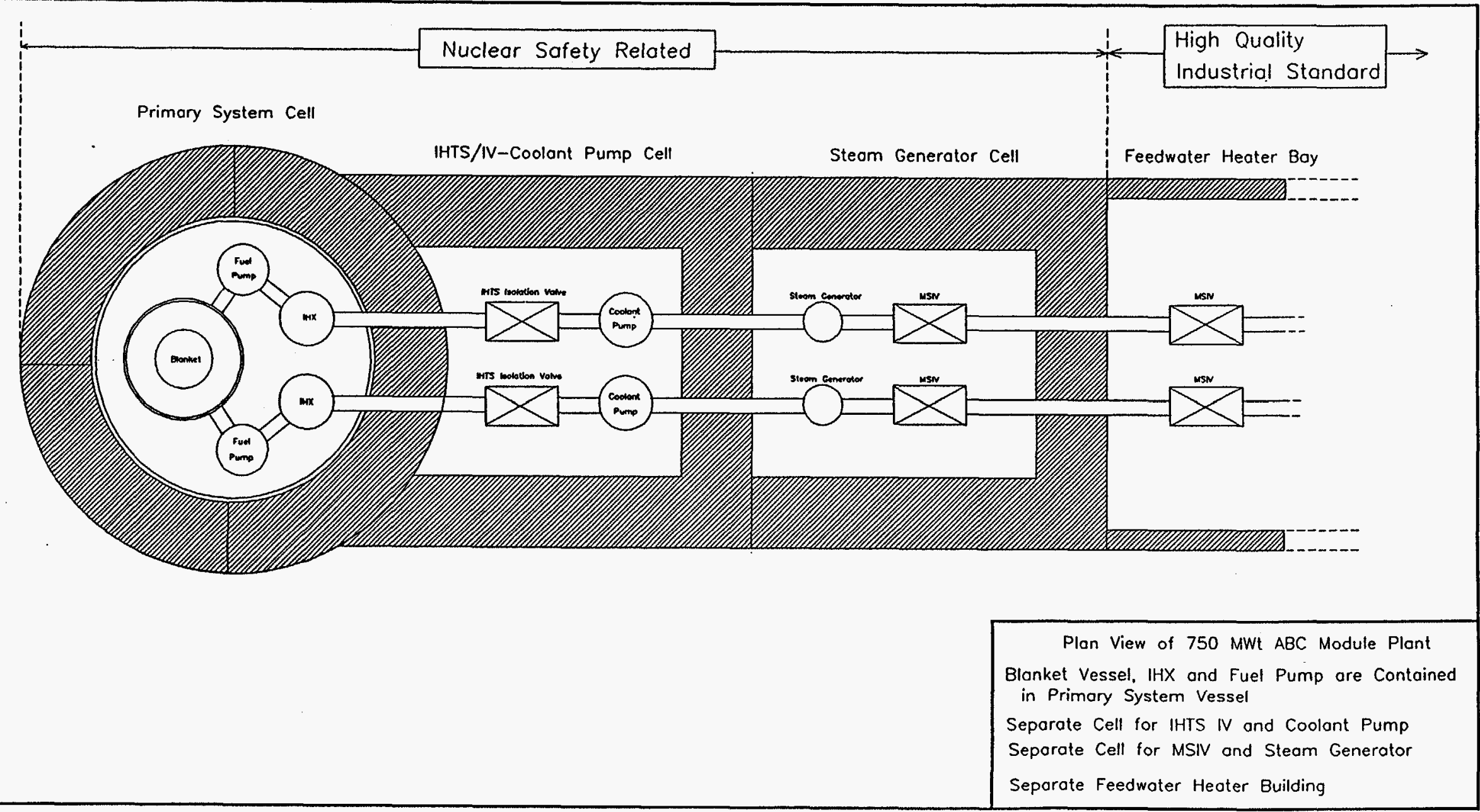

Fig. 18: Plan View of $750 \mathrm{MWt} A B C$ Module Train 


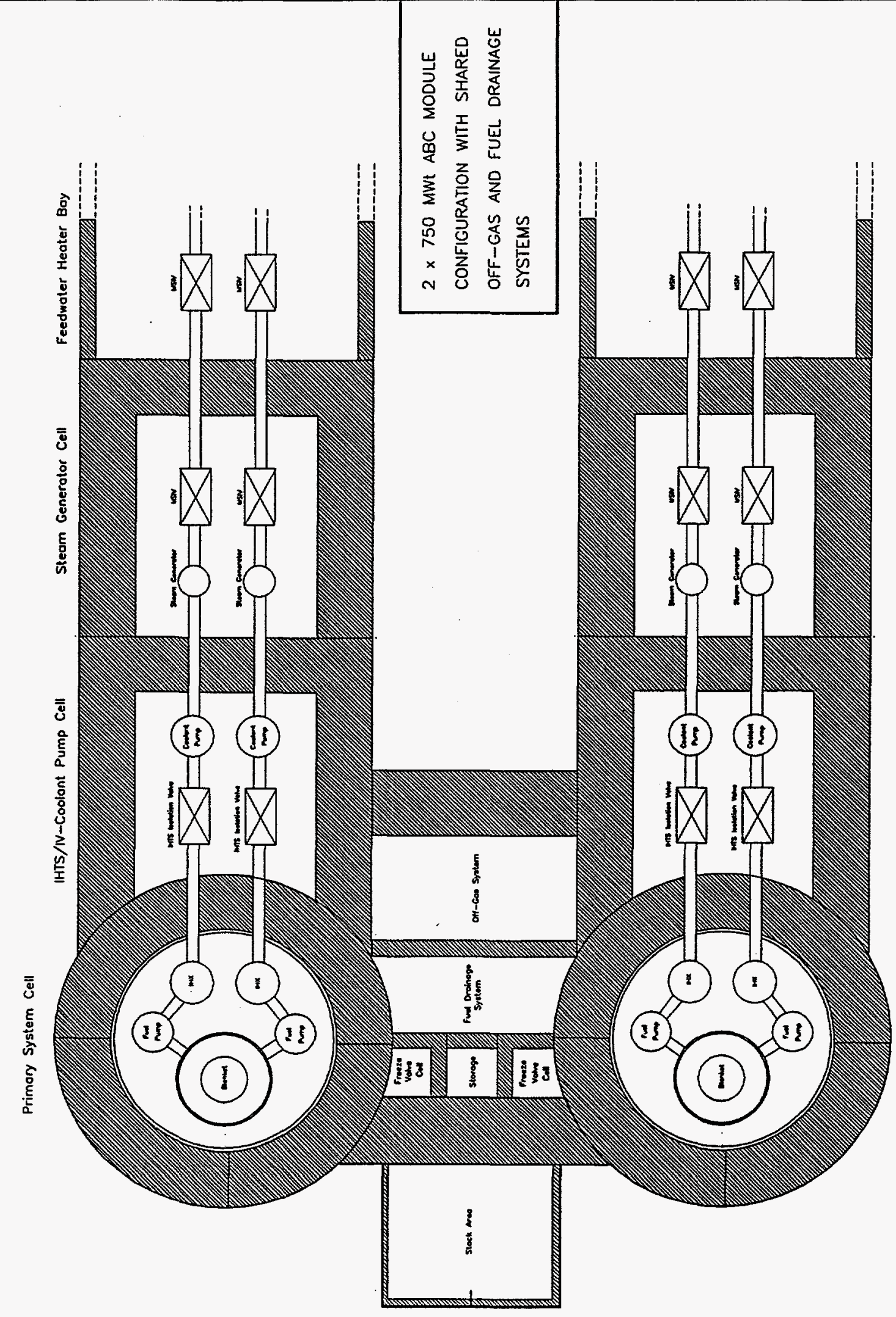

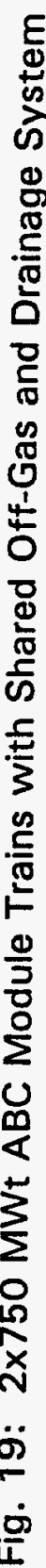




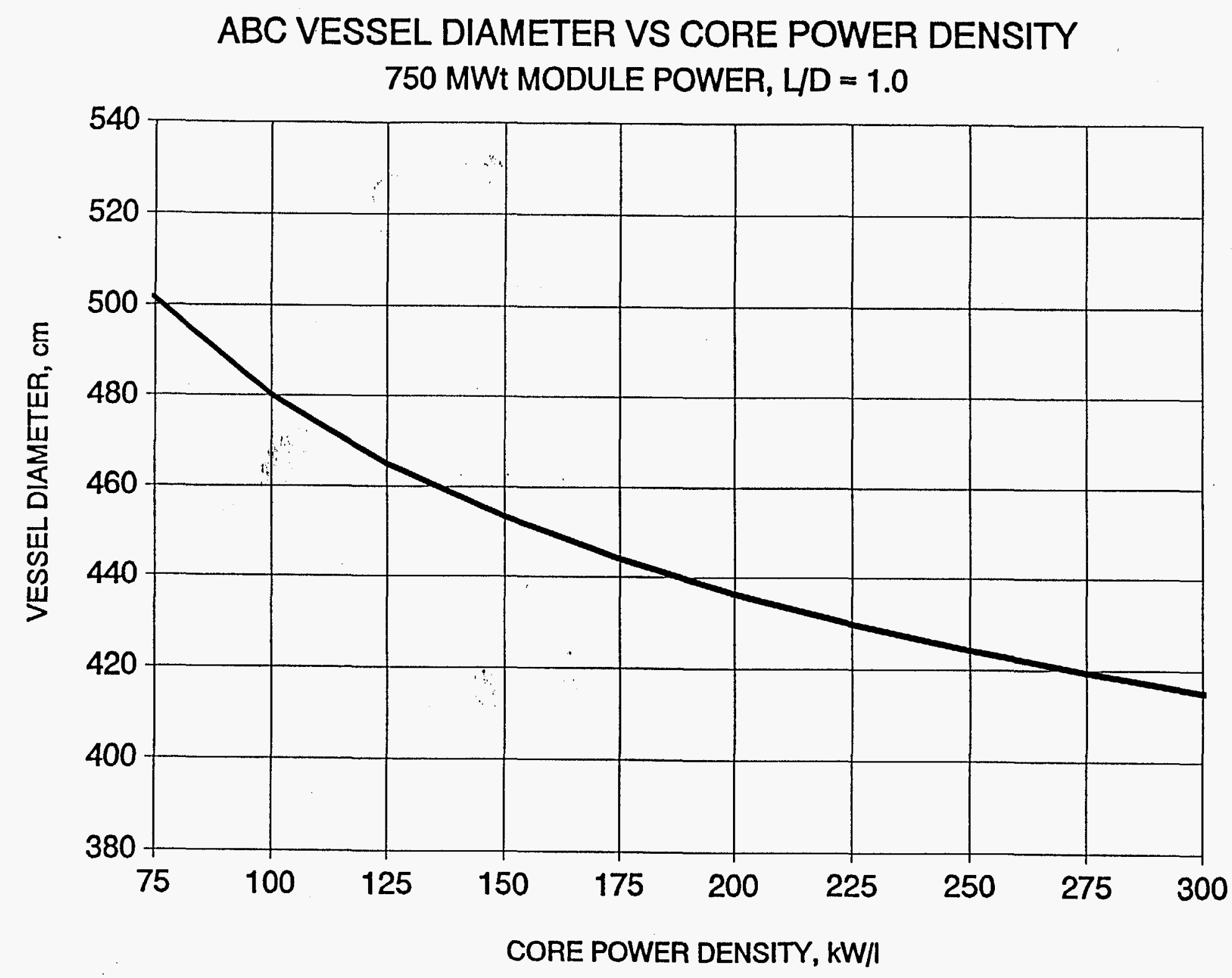

Fig. 20: $A B C$ Vessel Diameter as a Function of Core Power Density 


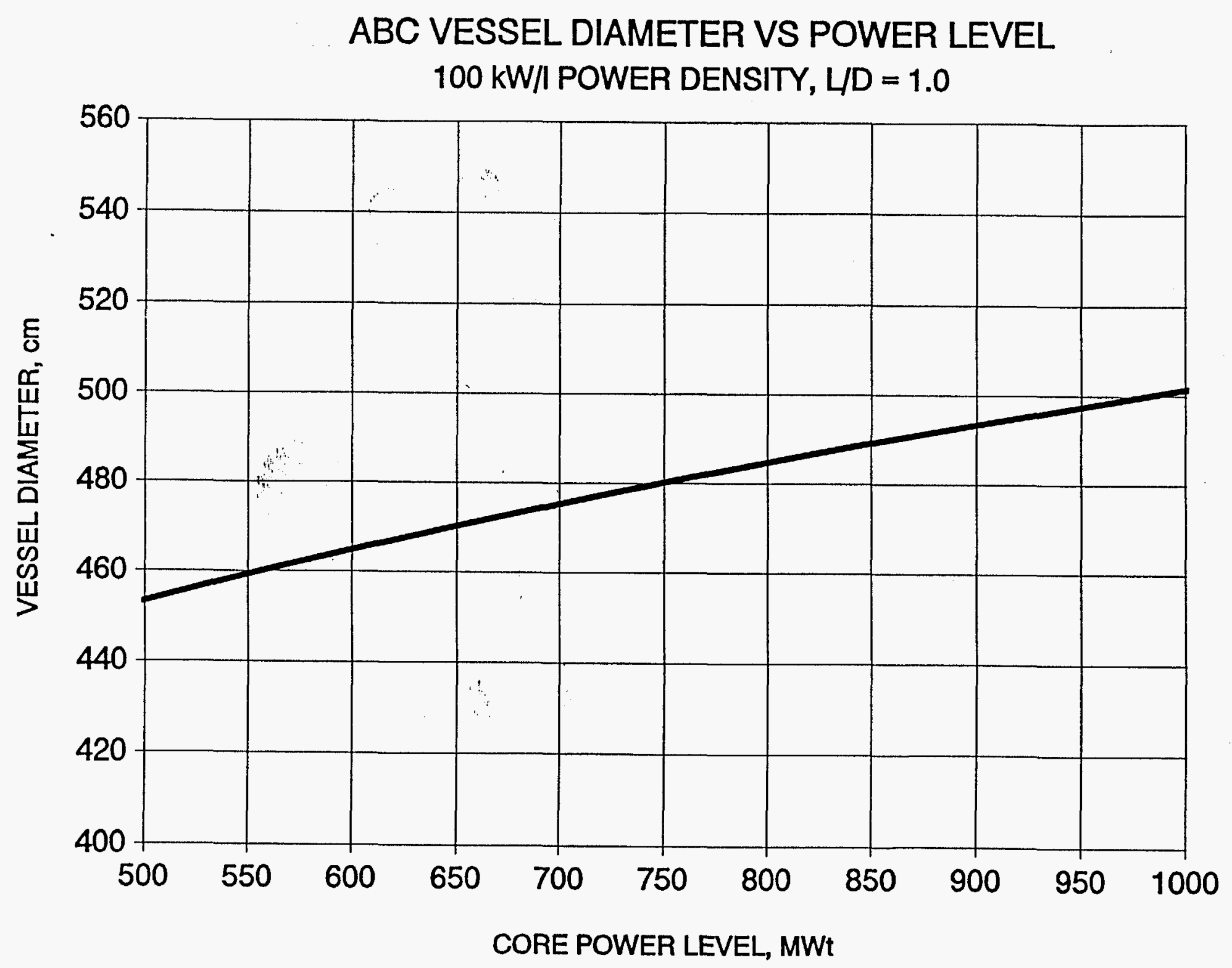

Fig. 21: $A B C$ Vessel Diameter as a Function of Power Level 


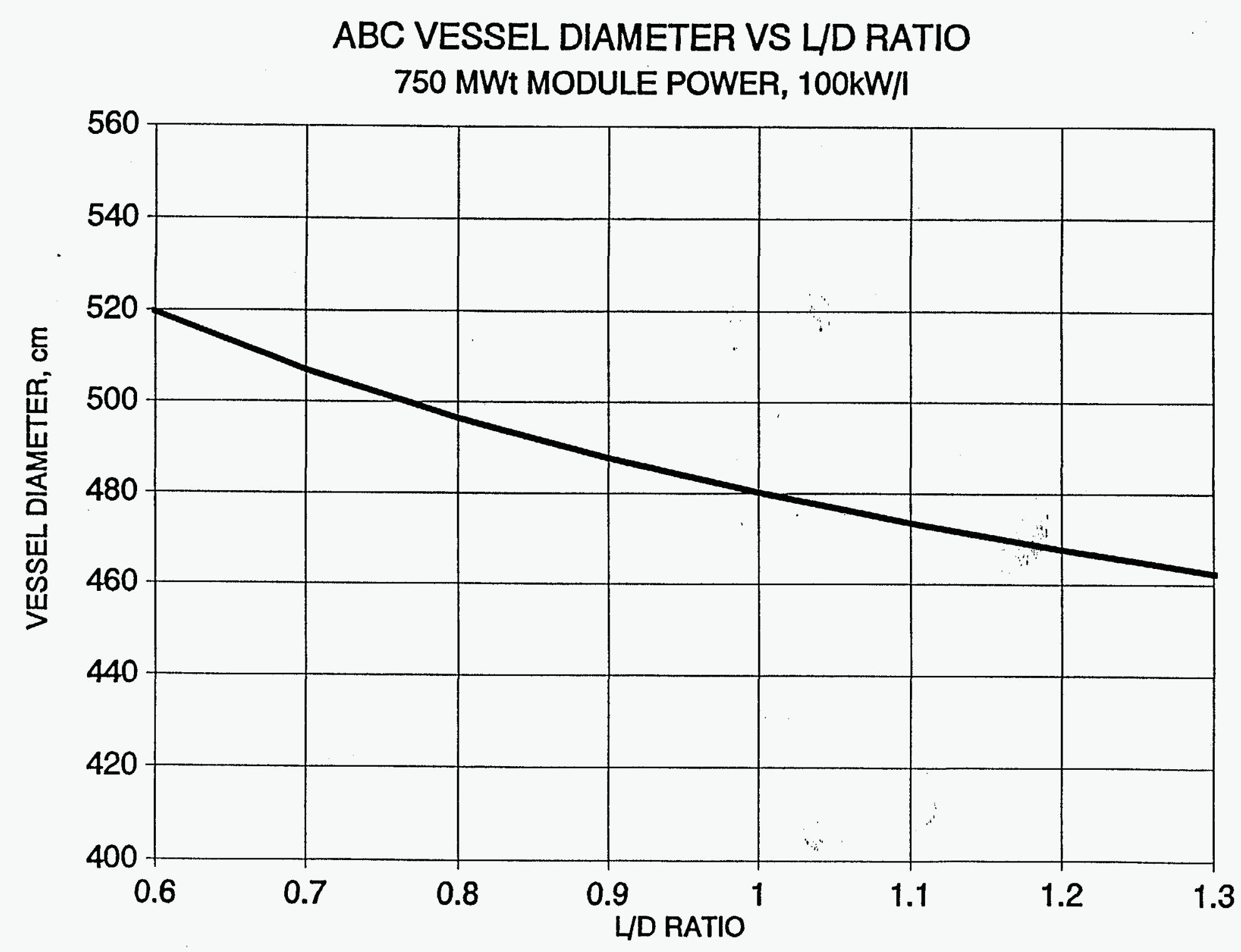

Fig. 22: $A B C$ Vessel Diameter as a Function of $L / D$ Ratio 